\title{
FROM RIGHT TO WRONG: GROUNDING A “RIGHT" TO PRIVACY IN THE “WRONGs” OF TORT
}

\author{
CHRIS D.L. HUNT ${ }^{*}$
}

This article discusses the theoretical foundations for a common law tort of invasion of privacy. The author argues that invading a person's "right" to privacy is conduct that can be regarded as a tortious "wrong." He illustrates this by integrating privacy into the work of several leading tort theorists and also by drawing analogies between privacy and defamation, on the one hand, and battery and trespass, on the other. He concludes that asking tort to protect privacy does not ask it to do work of a kind any different in substance from that which it has long been doing.
Cet article porte sur les principes théoriques de l'atteinte à la vie privée en tant que délit de common law. L'auteur fait valoir que le fait de porter atteinte $a u$ «droit » à la vie privée de quelqu'un peut être vu comme un comportement « délictuel ». Il le démontre en intégrant le respect de la vie privée dans les travaux de plusieurs grands théoriciens en matière de délit et en faisant un parallèle entre le respect de la vie privée et la diffamation d'une part et la voie de fait et l'entrée non autorisée d'autre part. Il conclut que le fait d'inclure le respect de la vie privée dans la responsabilité délictuelle ne changerait véritablement rien à ce qui se fait depuis longtemps.

\section{TABLE OF CONTENTS}

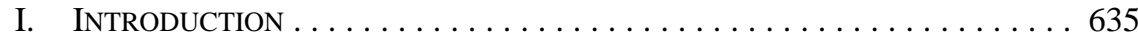

II. "PRIVACY” AND ITS UndeRlying VALUES . . . . . . . . . . . . 638

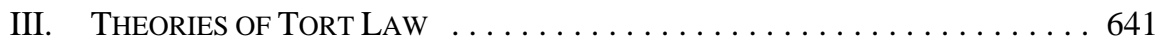

A. WHAT IS A TORT? . . . . . . . . . . . . . . . . . . . . . . 641

B. PRELIMINARY REMARKS CATEGORIZING

THE LITERATURE . . . . . . . . . . . . . . . . . . . 643

C. Formalistic Corrective JustiCE . . . . . . . . . . . . . . . 644

D. Substantive CoRreCtive JustiCE . . . . . . . . . . . . . . . . . . . 649

E. TORTS AS Rights, TORTS AS WrOngs . . . . . . . . . . . . 652

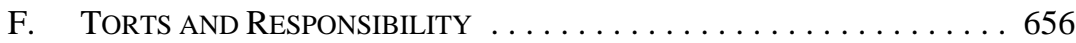

IV. ANALOGIES TO EXISTING TORTS . . . . . . . . . . . . . . . . . . 660

A. "Dignity” AND "Civility” PROTECTED

IN DEFAMATION AND PRIVACY $\ldots \ldots \ldots \ldots \ldots \ldots \ldots \ldots \ldots$

B. "PERSONAL EXCLUSIVITY” PROTECTED

IN TRESPASS AND PRIVACY $\ldots \ldots \ldots \ldots \ldots \ldots 64$

V. CONCLUSION .......................... 666

\section{INTRODUCTION}

Few subjects are as topical, or as fraught, as privacy. While courts in this country have long appreciated the importance of privacy as a constitutional right operating to restrain certain state behaviour, they have been notoriously reluctant, historically, to recognize discrete privacy rights in the purely private (as opposed to public) law context. This historic reluctance has recently been replaced with what one commentator calls a "privacy impulse.”1 This impulse has resulted in the recognition of civil actions for invasion of privacy in several

Faculty of Law, Thompson Rivers University, Kamloops, British Columbia.

See Lisa M Austin, “Privacy and Private Law: The Dilemma of Justification” (2010) 55:2 McGill LJ 165 at $167,169$. 
Commonwealth jurisdictions. Importantly, these actions rest on two very different doctrinal foundations. In England, ${ }^{2}$ the action is formally grounded in the equitable breach of confidence doctrine, whereas in Australia ${ }^{3}$ and New Zealand, ${ }^{4}$ tort law is the basis of these claims. Canadian courts, for their part, have thus far proceeded through the vehicle of tort, but unlike courts in these other jurisdictions, there has been no judicial analysis of why common law tort is preferable to equitable breach of confidence. ${ }^{5}$

Various academic commentators have criticized the English approach, arguing that equitable confidence is an inappropriate foundation for privacy claims. ${ }^{6}$ The basis of these criticisms is twofold. First, it has been noted that classical confidence doctrine requires that the parties be in a relationship of confidence in fact - something a peeping Tom, or a publishing paparazzo typically is not. In Campbell, the House of Lords dropped this traditional requirement, and imposed an obligation of confidence on a complete stranger, who was not in a confidential relationship with the claimant, based solely on the former's objective knowledge that the latter had a reasonable expectation of privacy in relation to the subject matter of the claim. ${ }^{7}$ The problem with this approach, commentators have noted, is that it amounts to a "startlingly radical" distortion that divorces confidence from its central policy rationale - namely that of preserving the "trust like" character of confidential relationships. ${ }^{8}$ The second criticism of the English approach also concerns the inherent limitations of confidence. It has been noted that breach of confidence is concerned, classically, with disclosures of confidential information, and that it simply makes no sense to regard a bare intrusion into one's private affairs (such as the peeping of a Tom) as a breach of confidence. Once it is accepted that privacy can in principle be violated by such bare intrusions, it becomes apparent that breach of confidence cannot — without conceptual distortion — form the basis of a comprehensive privacy regime. ${ }^{9}$

These academic criticisms have resonated with judges adjudicating privacy claims both in England and in New Zealand. In Douglas v. Hello! Ltd., the first English Court of Appeal

Campbell v MGN Ltd, [2004] UKHL 22, [2004] 2 AC 457 (especially Lord Hope at paras 85-87, Baroness Hale at para 134, and Lord Carswell at paras 162-63) [Campbell].

See ABC v Lenah Game Meats Pty Ltd, [2001] HCA 63, 208 CLR 199 [Australian Broadcasting Corp]. Note that members of the High Court of Australia expressed different views on this issue. Chief Justice Gleeson preferred the vehicle of confidence (at paras 34-39), whereas Justice Callinan appeared to prefer tort (at para 335). Justices Gummow and Hayne, for their part, were careful not to foreclose the future development of an independent privacy tort (at para 132), and subsequent lower court decisions have recognized that invasions of privacy can be tortious wrongs. See e.g. Jane Doe v Australian Broadcast Corporation, [2007] VCC 281. See also Grosse v Purvis, [2003] QDC 151.

$4 \quad$ Hosking $v$ Runting (2004), [2005] 1 NZLR 1 (CA) [Hosking].

See Jones $v$ Tsige, 2012 ONCA 32, 108 OR (3d) 241 [Jones]; $c f$ other lower court decisions assuming, without analysis, that if privacy invasions are actionable, tort law will ground the claim: Somwar $v$ McDonald's Restaurants of Canada Ltd (2006), 79 OR (3d) 172 (Sup Ct J); Caltagirone v ScozzariCloutier, [2007] OJ No 4003 (QL) (Sup Ct J).

6 See e.g. my argument in Chris DL Hunt, "Rethinking Surreptitious Takings in the Law of Confidence" [2011] 1 Intellectual Property Q 66 [Hunt, "Rethinking”]; cf Jillian Caldwell, "Protecting Privacy Post Lenah: Should the Courts Establish A New Tort or Develop Breach of Confidence?”(2003) 26:1 UNSW LJ 90; Des Butler, “A Tort of Invasion of Privacy In Australia?” (2005) 29:2 Melb UL Rev 339; Ayre Schreiber, "Confidence crises, privacy phobia: why invasions of privacy should be independently recognised in English Law” [2006] Intellectual Property Q 160.

$7 \quad$ Supra note 2.

$8 \quad$ Gavin Phillipson, "Transforming Breach of Confidence? Towards a Common Law Right of Privacy under the Human Rights Act" (2003) 66:5 Mod L Rev 726 at 746; I have advanced this argument in detail in Hunt, "Rethinking," supra note 6.

9 Jonathan Morgan, “Privacy, Confidence and Horizontal Effect: 'Hello’ trouble” (2003) 62:2 Cambridge LJ 444 at 457. 
decision to grapple with the modified confidence action emerging in Campbell, Lord Phillips suggested that invasions of privacy "might seem most appropriately to fall within the ambit of the law of delict" rather than equitable confidence. ${ }^{10}$ This sentiment was also endorsed by Lord Justice Sedley in an earlier appeal involving the same case. ${ }^{11}$ In Hosking, three members of the New Zealand Court of Appeal made similar points, with Justice Tipping asserting that tort provided a more "jurisprudentially straightforward" foundation for civil claims for invasion of privacy than breach of confidence. ${ }^{12}$

While the arguments against breach of confidence are convincing, it does not necessarily follow that tort provides a more satisfactory basis for privacy claims. Courts and commentators criticizing confidence have uniformly preferred tort, but to date this preference has been little more than an unexplored assumption. There has, in other words, been almost no positive analysis of why tort law can, or should, ground civil actions for invasion of privacy. Indeed, one prominent commentator has recently argued that civil claims for invasion of privacy continue to pose a theoretical "justificatory dilemma" for the law of torts. ${ }^{13}$ It is the purpose of this article to fill this gap, and thereby answer this dilemma, by evaluating the tort side of this equation. Specifically, it argues below that vindicating a "right" of privacy fits squarely within the province of the "wrongs" of tort.

How does one go about advancing such an argument? In my view, the first step must be to understand the essential nature and functions of tort law. Once we appreciate the essence of tort, we can then consider whether asking tort to protect privacy is sound in theory. Another approach is to reason by analogy. If we can identify fundamental commonalities between the interests underpinning privacy and those animating other long-established torts, we can suggest with some confidence that asking tort to protect privacy does not ask it to do work of a kind any different in substance from that which it has long been doing. Accordingly, the argument below proceeds in two phases. In Part III, I discuss the works of several influential tort theorists who purport to explain, at the most abstract level, the nature and purposes of tort law. This rich, nuanced, and complex theoretical literature suggests that tort law can be understood as a mode of legal ordering designed to vindicate rights which are in turn connected to the values of dignity and autonomy. I elucidate these theories including variations of corrective justice scholarship and other contemporary rights-based jurisprudence - and then apply these principles to the values underpinning privacy itself, with particular emphasis on scholarship that has explored the connection between privacy and these very same deontological values. This primary argument advanced in Part III is then buttressed with a subsidiary one in Part IV. There, I argue that a tort of invasion of privacy can be further justified by drawing analogies to existing torts, particularly defamation and battery. Drawing on the work of prominent commentators, it is argued that the core functions of defamation - namely, the protection of the claimant's dignity in reputation and the maintenance of civility rules for society more generally — are equally applicable to civil

Douglas v Hello! Ltd, [2005] EWCA Civ 595, [2005] 4 All ER 128 at para 96 [Douglas]; Campbell, supra note 2.

Douglas v Hello! Ltd (2000), [2001] 2 All ER 289 (CA) (contrasting confidence, which is closely related to breaches of trust, with privacy, which is not necessarily so concerned at para 126).

Hosking, supra note 4 at paras 245-46, cf para 48.

Austin, supra note 1 at 185 . The only other paper attempting to justify in some detail invasion of privacy as a tortious wrong is Russell Brown, "Rethinking Privacy: Exclusivity, Private Relation and Tort Law" (2006) 43:3 Alta L Rev 589 [Brown, “Privacy”]. 
actions for invasion of privacy; and that battery's foundational justification — namely, the vindication of personal "exclusivity" - is analogous to privacy's core concern of marking a personal zone that others ought to treat as inviolate. Before advancing the above arguments in Parts III and IV, Part II first sets out a précis of some of the multifarious values said to underpin the right to privacy. This work is necessary to facilitate subsequent crossreferencing.

Before moving to this theoretical work, it is worth highlighting, at the outset, that tort law is not hampered by the twin doctrinal limitations of equitable confidence. Recall that breach of confidence bites at the disclosure of information. Many torts (such as battery) vindicate intrusions into protected interests irrespective of subsequent disclosures - a point explored more fully below. Furthermore, recall that, due to its equitable origins, an obligation of confidence should not arise unless there is in fact an antecedent relationship of confidence. ${ }^{14}$ As explained below, in tort the relationship between the parties is notional or symbolic, and need not be a factual one. Thus, unlike breach of confidence, tort is capable, ostensibly at least, of protecting against bare intrusions and can impose obligations on strangers. This vests tort with an immediate jurisdictional appeal, which probably accounts for the judicial intuition that tort law provides a "jurisprudentially straightforward" doctrinal basis for invasion of privacy. The arguments below seek to confirm, through theoretical explication, the veracity of this judicial intuition.

\section{II. “PRIVACY” AND ITS UNDERLYING VALUES}

Many eminent scholars have developed theoretical definitions of privacy - that is to say, accounts of what makes a matter private or not at a purely conceptual level. ${ }^{15}$ Despite this large, complex, and growing body of work, privacy remains a deeply contested concept. ${ }^{16}$ It is well beyond the scope of this paper to engage with this literature. Consequently, where the term "privacy" is used, it refers to an intuitive sense rather than to any particular conceptual articulation. It is worth emphasizing that this approach need not compromise the analysis as many of these theorists anchor their conceptual definitions of privacy in basic intuition. ${ }^{17}$

Notwithstanding the many nuanced disagreements, virtually every commentator agrees that any proper conception of privacy must capture two types of invasions: bare intrusions into a person's privacy (such as the peeping Tom) and disclosures of private information (such as publishing a person's medical information on the Internet). The privacy torts in New Zealand, ${ }^{18}$ the United States, ${ }^{19}$ and Australia ${ }^{20}$ all capture these two dimensions of privacy,

For a discussion of leading privacy theories, see Chris DL Hunt, "Conceptualizing Privacy and Elucidating its Importance: Foundational Considerations for the Development of Canada's Fledgling Privacy Tort” (2011) 37:1 Queen's LJ 167 [Hunt, “Conceptualizing”].

16 WA Parent, "A New Definition of Privacy for the Law" (1983) 2:3 Law \& Phil 305 (privacy jurisprudence is in "conceptual shambles" at 305); Robert C Post, "Three Concepts of Privacy" (2001) 89:6 Geo LJ 2087 (Post "sometimes despair[s] whether [privacy] can be usefully addressed at all" at 2087).

For a discussion, see Hunt, “Conceptualizing,” supra note 15 at 177-78.

Hosking, supra note 4 (disclosure); C v Holland, [2012] NZHC 2155, [2012] 3 NZLR 672 (intrusion). See The American Law Institute, Restatement of the Law, Second: Torts, Tentative Draft No 13 (Philadelphia: The American Law Institute, 1967) at §§ 652B-652E.

Australian Broadcasting Corp, supra note 3 at para 125 (noting both dimensions of privacy). 
as do the statutory privacy torts operating in four Canadian provinces. ${ }^{21}$ The English privacy/confidence action was initially limited to informational disclosures, but is evolving to capture bare intrusions. ${ }^{22}$ At present, the common law privacy tort recognized in Ontario extends only to intrusions, ${ }^{23}$ but there is no reason to believe it will not evolve to capture disclosures in the future. ${ }^{24}$ For the purposes of this article, I will assume that any intuitive understanding of privacy must include a right to be free from certain intrusions and disclosures, and the argument will proceed on the basis that any effective privacy tort must therefore capture both of these dimensions. ${ }^{25}$

Privacy theorists have also devoted considerable space to elucidating the multifarious values said to underpin the right to privacy. Below, we will see that many of these same values play an important role in the theoretical accounts of tort law developed by theorists in that field. It is worth briefly sketching some of these privacy values here, at the outset, to facilitate subsequent cross-referencing.

Theorists often divide privacy's values into two broad categories. ${ }^{26}$ The first concerns arguments about the deontological importance of privacy. Deontologists focus on the intrinsic value of privacy, as a right inherent to an individual's existence as a "human person." 27 Scholars in this vein typically make reference to the importance of dignity, autonomy, and personhood, and explain how invasions of privacy offend each of these overlapping human values. Dignity is typically framed in Kantian terms, importing a right to be treated as an end in oneself, not as a means to other people's ends. ${ }^{28}$ Invasions of privacy are said to offend Kantian dignity for they involve the invader placing his wishes above the rights holder. ${ }^{29}$ Moreover, privacy invasions — such as the peeping of a Tom are said to objectify the victim, and thereby evidence a lack of respect for him as a human person with his own sensibilities and preferences. ${ }^{30}$ Autonomy refers to the capacity for an individual to "liv[e] their life in accordance with their own particular ideas of the individual good." ${ }^{11}$ Theorists note that forced disclosures undermine autonomy inasmuch as they

See Privacy Act, RSBC 1996, с 373; The Privacy Act, RSS 1978, с P-24; The Privacy Act, CCSM c P125; Privacy Act, RSNL 1990, c P-22.

Imerman $v$ Tchenguiz, [2010] EWCA Civ 908, [2011] 1 All ER 555 (simply looking at private information, without any subsequent disclosure, is actionable in principle at para 69); $R$ (Wood) $v$ Metropolitan Police Commissioner, [2009] EWCA Civ 414, [2009] 4 All ER 951 (taking photographs in public place may infringe privacy even if not subsequently disclosed at para 34); CTB v News Group, [2011] EWHC 1326 (QB) ("the modern law of privacy is not concerned solely with information or 'secrets': it is also concerned importantly with intrusion" at para 23 [emphasis in original]). Jones, supra note 5 at para 70.

For elaboration, see Chris DL Hunt, "Privacy in the Common Law: A Critical Appraisal of the Ontario Court of Appeal’s Decision in Jones v. Tsige” (2012) 37:2 Queen’s LJ 665 at 672.

Again, which intrusions and disclosures offend privacy is a deeply contested issue, the answer to which depends on the nuances of one's conception of privacy. Pursuing those niceties is well outside the scope of this article.

For a detailed discussion, with many sources, see Hunt, “Conceptualizing,” supra note 15 at 201-19. Hilary Delany \& Eoin Carolan, The Right to Privacy: A Doctrinal and Comparative Analysis (Dublin: Thompson Roundhall, 2008) at 12.

For authors grounding their deontological arguments in Kantian ethics, see Hunt, "Conceptualizing," supra note 15 at 203-205.

NA Moreham, "Why is Privacy Important?” Privacy, Dignity and the Development of the New Zealand Breach of Privacy Tort” in Jeremy Finns \& Stephen Todd, eds, Law, Liberty, Legislation: Essays in honour of John Burrows QC (Wellington: LexisNexis NZ, 2008) 231 at 236-37.

Jeffrey Rosen, “The Purposes of Privacy: A Response” (2001) 89:6 Geo LJ 2117 at 2124; cf Stanley I Benn, "Privacy, Freedom, and Respect for Persons” in J Roland Pennock \& John W Chapman, eds, Nomos XIII: Privacy (New York: Atherton Press, 1971) 1 at 6-7; Ruth Gavison, "Privacy and the Limits of Law” (1980) 89:3 Yale LJ 421 at 455.

31 Beate Rössler, The Value of Privacy, translated by RDV Glasgow (Cambridge: Polity, 2005) at 43. 
compel a person to release information against their will. ${ }^{32}$ It has also been argued that overt watching, without permission, undermines autonomy for it produces real changes in the victim's behaviour. ${ }^{33}$ Moreover, covert spying is offensive because it deprives the victim of her opportunity to choose for herself how to behave. This is because people choose how to act based on context, and if they are deceived about who is watching them - because a "Tom" is peeping surreptitiously, say — their choice to behave a certain way is inherently misinformed. As Benn famously put it: “Covert observation ... is objectionable because it deliberately deceives a person about his world, thwarting, for reasons that cannot be his reasons, his attempts to make a rational choice." ${ }^{34}$ Finally, commentators invoke the notion of personhood, which refers to the individual's perceived moral independence from the mass of society. Theorists argue that invading another's privacy sends the message to him, and to society more generally, that the victim is not entitled to control access to himself or to his personal information. This, in turn, undermines the victim's sense of himself as an individual self, part of, but distinct from, the rest of society. ${ }^{35}$ Insofar as a measure of privacy is necessary for a person to experience moral title over himself, it is thus also a "precondition to personhood." 36 It has also been argued that respect of privacy is a precondition to the development of a capacity for genuine autonomy. ${ }^{37}$ This is because the exercise of autonomy requires people to take themselves seriously as independent moral actors in the sense that they believe their own choices are important. Privacy invasions send the opposite message, and can have the insidious effect of discouraging people from exercising autonomous choices in the future. ${ }^{38}$

The second category of scholarship devoted to exploring privacy's values can be called the instrumentalists or consequentialists. These scholars offer utility-based arguments. For them, the importance of privacy lies in the promotion of various goods that flow (to the individual and to society) from its protection or are undermined by its violation. ${ }^{39}$ The psychologist Sidney Jourard has detailed the importance of privacy as providing a sanctuary, where a person is free from social pressures to conform, and has noted that preserving this space (from unwanted intrusions or informational disclosures) is a prerequisite to emotional well-being. ${ }^{40}$ Others have emphasized the connection between a respected zone of privacy and the human flourishing it promotes, such as the confidence to test controversial ideas in

32 See Hunt, “Conceptualizing,” supra note 15 at 205-206.

33 See Charles Fried, "Privacy” (1968) 77:3 Yale LJ 475 at 483-84; cf Daniel J Solove, “A Taxonomy of Privacy” (2006) 154:3 U Pa L Rev 477 at 495.

34 Benn, supra note 30 at 10 [emphasis in original]; cf Hyman Gross, "Privacy and Autonomy” in Pennock \& Chapman 169, supra note 30 (secret surveillance is offensive to dignity and autonomy because the victim is deprived of capacity to make an autonomous informed choice about how to present herself at 172-74).

35 Jeffrey H Reiman, “Privacy, Intimacy, and Personhood” (1976) 6:1 Philosophy \& Public Affairs 26 at 36-44; cf Hunt, "Conceptualizing,” supra note 15 at 207-209.

36 Reiman, ibid at 39; $c f$ Francis S Chlapowski, "The Constitutional Protection of Informational Privacy” (1991) 71:1 BUL Rev 133 at 153-55.

37 See David Feldman, "Secrecy, Dignity, or Autonomy? Views of Privacy as a Civil Liberty” (1994) 47:2 Current Leg Probs 41 at 54-5; cf Fried, supra note 33 at 479.

38 See Reiman, supra note 35 at 40-41, discussing the work of influential sociologist Erving Goffman, who in turn discusses the panoptic effect in prisons whereby inmates under constant surveillance sacrifice autonomy and individuality for conformity; $c f$ Edward J Bloustein, "Privacy as an Aspect of Human Dignity: An Answer to Dean Prosser” (1964) 39:6 NYUL Rev 962 at 1003.

$39 \quad$ For a detailed discussion, with many sources, see Hunt, "Conceptualizing," supra note 15 at 209-17.

40 Sidney M Jourard, “Some Psychological Aspects of Privacy” (1966) 31:2 Law \& Contemp Probs 307 at 307-309; cf Benn, supra note 30 (privacy as sanctuary required for people to remain sane at 19-21). 
secret before choosing to express them publicly. ${ }^{41}$ This latter point — that privacy promotes free expression ${ }^{42}$ — has been the subject of considered commentary by scholars who note that if this is true, then respect for privacy is also important for the maintenance of a healthy democracy. ${ }^{43}$ Democracy depends on an autonomous citizenry that is free to formulate and express unconventional - indeed controversial - views. If invasions of privacy inhibit individuality and produce conformity, as many scholars have argued, then democracy itself may suffer.

\section{THEORIES OF TORT LAW}

In this section, I discuss the work of leading tort theorists and argue that asking tort law to protect privacy does not ask it to do work of a kind any different in substance from that which it is already doing. In other words, the argument is that invading a person's "right" to privacy is conduct that fits within the structural reasoning, and normative foundations, of tortious "wrongdoing." Before moving to this discussion, it is worth first defining "tort" in the abstract, and then categorizing the theoretical literature.

\section{A. WHAT IS A TORT?}

Lawyers identify torts by pointing to existing heads of liability. If pressed for a definition, most would probably reply "a tort is a wrong.” Etymologically, this is correct: "tort” derives from the Latin "tortus" meaning "twisted," which evolved in French to mean "wrong."44

Of course, the label "wrong” is too broad. To refine the concept, three distinctions should be drawn. First, "wrongfulness" in tort cannot be coextensive with moral wrongdoing. Although many theorists argue morality is a crucial consideration underpinning most torts, obviously not every immoral act is tortious. Lying is probably immoral, but without more it is not actionable. ${ }^{45}$ Torts are wrongs in the sense that they violate legal, rather than purely moral, norms. ${ }^{46}$ Second, we must distinguish between wrongdoing in private and public law. Crimes, such as trafficking marijuana, are legal “wrongs," yet their commission will not give rise to tortious liability. This is because the obligation not to traffic is a duty owed to society, not to any specific individual. ${ }^{47}$ Most theorists agree that the distinguishing feature of private (as opposed to public) law duties is the principle of "bipolar correlativity" which, as

See Gross, supra note 34 (noting privacy promotes self criticism, growth, and moral introspection, all necessary to human flourishing at 176).

See Eric Barendt, "Privacy and freedom of speech" in Andrew T Kenyon \& Megan Richardson, eds, New Dimensions in Privacy Law: International and Comparative Perspectives (Cambridge: Cambridge University Press, 2006) 11 (elaborating on how respecting privacy promotes freedom of conscience and free speech at 24-30).

Julie E Cohen, “Examined Lives: Informational privacy and the Subject as Object” (2000) 52:5 Stan L Rev 1373 at 1425-27.

Robert Stevens, Torts and Rights (Oxford University Press, 2007) (“[i]n modern French, 'tu as tort' means 'you are wrong'” at 2) [Stevens, Torts].

On the distinction between law and morality in the context of torts, see: John CP Goldberg \& Benjamin C Zipursky, “Torts as Wrongs” (2010) 88:5 Tex L Rev 917 at 929-32, 947-57; Peter Cane, Responsibility in Law and Morality (Oxford: Hart Publishing, 2002) at 1-28 [Cane, Responsibility]; Peter Cane, The Anatomy of Tort Law (Oxford: Hart Publishing, 1997) at 25-7 [Cane, Anatomy]; Peter Birks, "The Concept of a Civil Wrong” in David G Owen, ed, Philosophical Foundations of Tort Law (Oxford: Clarendon Press, 1995) 31 at 37 [Birks, “Civil”]; Ernest J Weinrib, The Idea of Private Law (Cambridge, Mass: Harvard University Press, 1995) at 109-13 [Weinrib, Idea].

Birks, “Civil,” ibid at 33; Goldberg \& Zipursky, ibid at 918, 929-32.

Stevens, Torts, supra note 44 at 284; Goldberg \& Zipursky, ibid at 918, 946. 
discussed below, is the conceptual link uniting the claimant and defendant as doer and sufferer of the same injustice, giving the former the right to sue in his own name. ${ }^{48}$ Third, even within private law, torts must be distinguished from other forms of civil liability. Peter Birks, the most influential taxonomist of English private law, adopted a fourfold classification turning on events which generate rights of civil action. These are: contract (consent), tort (wrong), unjust enrichment, and "other causative events." 49 According to Birks, "tort” must occupy its own distinct category within private law because liability in tort can only be explained by recourse to the notion that defendant (D) has breached a primary duty owed to claimant (C) (this is the event which creates a right to sue), whereas the right to sue in these other categories can be explained without invoking the notion that $\mathrm{D}$ has breached a primary duty. ${ }^{50}$ Furthermore, tort is distinct because, unlike the other categories in which the appropriate measure of relief is largely intuitive, relief for tortious wrongdoing is entirely a matter of policy — no natural remedy is dictated by the facts. ${ }^{51}$

So, a tort is a legal (not a purely moral) wrong, and C's right to sue D emerges once D has breached a duty he owes to $\mathrm{C}$ (as opposed to one he owes to society). ${ }^{52}$ While this refined definition serves to isolate "torts" within the law, it nevertheless must remain broad and abstract in order to capture the diverse heads of liability found in tort doctrine. Tort law developed rapidly in the eighteenth century in a haphazard manner as a litigant-driven process under the writs of trespass and trespass upon the special case. ${ }^{53}$ The legacy of this process is still felt, as tort now covers a “'loose federation' of heads of liability” which ostensibly serve a "plethora of different juristic and social functions." ${ }^{4}$ Many commentators criticize tort as lacking “conceptual integrity,” which, at first glance, certainly seems to be the case. ${ }^{55}$ It is the self-styled job of tort theorists to bring coherence to this varied body of law, by elucidating its internal structure and normative foundations in an effort to identify unifying characteristics.

Weinrib, Idea, supra note 45, ch 5; Richard W Wright, "Right, Justice and Tort Law” in Owen 159, supra note 45 at 171; Robert Stevens, "Rights and Other Things” (2010) at 37-38 [unpublished], online: SSRN < http://ssrn.com/abstract=1648954> [Stevens, "Other”]; Cane, Anatomy, supra note 45 at 11-12. Birks, "Civil," supra note 45 at 32, 46-51; Peter Birks, "Equity in the Modern Law: An Exercise in Taxonomy” (1996) 26:1 UWA L Rev 1 at 10; for a different taxonomy of tort, focusing on tort as protecting inherently different interests than other branches of private law, see Cane, Anatomy, supra note 45 at 182-96; for a criticism of Birks' taxonomy, and an argument that torts should be structured around rights which impose correlative duties of non-interference, see Stevens, Torts, supra note 44, ch 13.

. Bivil," ibid at 34, 46-51 (in the case of mistaken payments, for instance, enrichment at another' expense is actionable because C's intent to transfer was impaired, a factor the "law regards as sufficient to characterize your enrichment as unjust,” at 48, without having to speak of any primary duty D owed to C. For contracts, the contract itself can explain why failure to perform generates liability, at 50-51). Ibid ("[in tort the] law has a free choice of what it shall be, subject only to extrinsic considerations such as the values of proportionality, determinancy, humanity, and so on” at 47). This contrasts with unjust enrichment, in which the measure of relief is naturally the restitution of benefits conferred, and contract law where it is obviously the value of the promise.

52 Ibid ("[a tort] is no more nor less than a breach of a legal duty owed to a plaintiff" at 33); $c f$ Goldberg \& Zipursky, supra note 45 at 937.

$53 \quad$ For a brief discussion, see Cane, Anatomy, supra note 45 at 2-10; Eric Descheemaeker, "Protecting Reputation: Defamation and Negligence” (2009) 29:4 Oxford J Leg Stud 603 at 606-608 (trespass initially applied to a set of identified wrongs, but later came to entail no more than the infringement of an existing right as pronounced in previous decisions; trespass upon the case was a gap-filling action in which litigants who could not identify an action in the Register of Writs pled novel facts and hoped for relief. Decisions rendered here solidified into forms of action and later into modern causes of action). Cane, Anatomy, ibid at 197.

$55 \quad$ See e.g. Goldberg \& Zipursky, supra note 45 at 937. 


\section{B. PreliminARY REMARKS CATEgorizing THE LiteratURE}

The difficulty of the task facing theorists - already complicated by the diversity of torts that ostensibly defy a single explanation — is exacerbated because tort doctrine appears to be divided along two fundamentally different lines. Andrew Burrows describes tort law as "bifocal." ${ }^{56}$ Most torts are arranged around the specific rights they are designed to protect (defamation: protecting reputation; battery: protecting bodily integrity and exclusivity, etc.), whereas negligence runs across these and is seemingly concerned not with protecting interests and vindicating rights but with degrees of fault ${ }^{57}$ and compensation for harm. ${ }^{58}$

This bifocality of doctrine has implications for tort theory. First, in attempting to accommodate the diversity of torts under one theory, commentators tend to frame their arguments at a high level of abstraction, which others lament has resulted in an esoteric and inaccessible literature, ${ }^{59}$ in which scholars largely talk past each other. ${ }^{60}$ Second, the bifocality of doctrine has caused a bifurcation of theory. Early theorists explained personal injury law (originally consisting of intentional torts) using what George Fletcher has called a "paradigm of reciprocity." ${ }^{1}$ The focus of the tort inquiry was resolved solely by reference to the behaviour of the parties to the dispute, and was guided by questions of moral fairness. ${ }^{62}$ This analysis centred on the idea (stemming from the writ system) that the law protected certain interests, interference with which gave rise to liability. ${ }^{63}$ This conception is reflected in the pioneering work of Justice Thomas Cooley, whose influential nineteenth century Treatise on the Law of Torts presented tortious wrongdoing as the violation of legal rights. ${ }^{64}$ As negligence law emerged and expanded, it posed challenges for this understanding of tort law. Fletcher has observed, that in response, a new "reasonableness" paradigm developed in which notions of "fault" were not adjudicated solely by reference to the defendant's interference with the claimant's protected interests, but instead turned on whether D caused harm to $\mathrm{C}$ unreasonably ${ }^{65}$ - an inquiry that necessitated looking beyond the behaviour of the parties to consider whether imposing liability would maximize social utility. ${ }^{66}$ This latter

Andrew Burrows, ed, English Private Law, 2nd ed (Oxford: Oxford University Press, 2007) at §17.13. See Descheemaeker, supra note 53 (endorsing Burrows’ characterization at 603).

Jason NE Varuhas, “A Tort-Based Approach to Damages under the Human Rights Act 1998” (2009) 72:5 Mod L Rev 750 (contrasting torts whose main purpose is to vindicate rights with negligence whose purpose is to compensate for harm at 764, n 108).

Peter Cane, “The Anatomy of Private Law Theory: A 25th Anniversary Essay” (2005) 25:2 Oxford J Leg Stud 203 at 205 [Cane, "Anniversary”].

Izhak Englard, "The Idea of Complimentarity as a Philosophical Basis for Pluralism in Tort Law” in Owen 183, supra note 45 at 185; George P Fletcher, "Against Reductionism: Some Comments on Ripstein” (Paper presented at the Conference on Tort Law and the Modern State, September 2006) [unpublished] cited in Russell Brown, "Rights-Based Tort Theory Acquires New Ambition” (2008) 47:1 Can Bus LJ 113 (tort theory resembles "an expressionist art show, where each theorist presents his or her version of the just tort law, and no two representations seem to have the same reality in common" at 114, n 11) [Brown, “Ambition”].

See George P Fletcher, "Fairness and Utility in Tort Theory” (1972) 85:3 Harv L Rev 537 at 540 [Fletcher, "Fairness”].

Ibid at 540, 543-56.

Ibid at 556 .

Thomas M Cooley, A Treatise on the Law of Torts (Chicago: Callahan, 1879); see also David W Leebron, “The Right to Privacy's Place in the Intellectual History of Tort Law" (1991) 41:3 Case W Res L Rev 769 at 781-82.

Fletcher, "Fairness," supra note 61 at 556-64.

Ibid at 557; $c f$ Leebron, supra note 64 at 808; Goldberg \& Zipursky, supra note 45 (similar discussion of emergence of early tort paradigms at 920-28). 
approach is reflected in the work of Oliver Wendell Holmes who thought tort doctrine should be based on utilitarian considerations. ${ }^{67}$

Fast-forward nearly a century and these two general paradigms broadly reflect the approaches of contemporary tort theorists. As negligence has grown into the über-tort, American scholarship has become dominated by questions of "cost-spreading, riskdistribution and cost-avoidance.”68 Questions of social utility have become increasingly "fashionable," 69 and utility theorists have developed sophisticated accounts drawing on economic principles of efficiency and wealth maximization both to explain and critique the operation of negligence law. ${ }^{70}$ Outside America, theorists have been more attracted to the "reciprocity" paradigm, which has grown into what Cane calls the modern "justice tradition." ${ }^{71}$ These scholars largely eschew conceiving of tort law in purely instrumentalist terms, preferring to understand it as an "autonomous universe of normative discourse based on concepts of 'rights,' 'wrongs,' 'responsibility' and ... 'justice.,”72

In what follows, I focus on the latter paradigm as this is the most apposite for explaining intentional torts that respond to protected interests. Torts on this side of the bifocal divide are the most relevant for any privacy tort. ${ }^{73}$ Below, I discuss three closely related schools in this paradigm: (1) corrective justice, (2) torts as "rights" and "wrongs," (3) and torts and "responsibility.” Before applying these paradigms to invasions of privacy, I must, perforce, spend some considerable space explicating their (sometimes elaborate) terminological nuances.

\section{Formalistic CORRECTIVE JUSTICE}

A discussion of contemporary tort theory must pay particular attention to corrective justice (CJ), and especially to the version developed by its leading advocate, Ernest Weinrib. ${ }^{74}$

67 OW Holmes Jr, The Common Law (Boston: Little Brown, 1881) at 94-6.

68 Fletcher, "Fairness," supra note 61 at 537.

$69 \quad$ Ibid at 538.

$70 \quad$ For an overview, see Cane, “Anniversary,” supra note 59.

$71 \quad$ Ibid at 204-205.

72 Ibid at 205. Despite the different focus of these two broad paradigms, members of each camp have sought to explain doctrines on the other side of the bifocal divide. See e.g. Weinrib, Idea, supra note 45 (Weinrib, the leading corrective justice scholar who rejects considerations of utility applies his theory to negligence); Richard A Posner, “The Right of Privacy” (1978) 12:3 Ga L Rev 393 (Posner, the most influential law and economics scholar, who believes questions of efficiency and wealth maximization are crucial, explains intentional torts - including invasion of privacy - in terms of economic utility). See Robert C Post, "The Social Foundations of Privacy: Community and Self in the Common Law Tort" (1989) 77:5 Cal L Rev 957 at 964, n 42 [Post, “Community”].

74 Jules Coleman is the other major proponent of CJ. His views are broadly consistent with Weinrib’s, especially since Coleman has retreated from his "pure annulment thesis” and now embraces bipolar correlativity; see Jules L Coleman, “The Mixed Conception of Corrective Justice” (1992) 77:2 Iowa L Rev 427 at 433; Jules L Coleman, The Practice of Principle: In Defence of a Pragmatic Approach to Legal Theory (Oxford: Oxford University Press, 2001) at 67-69 [Coleman, Principle]. For Weinrib’s view that he and Coleman now offer very similar accounts of CJ, see: Ernest J Weinrib, "Correlativity, Personality, and the Emerging Consensus on Corrective Justice” (2001) 2:1 Theor Inq L 107 at 126-33 [Weinrib, "Personality"]. For an argument that Coleman is a "de facto formalist" who concentrates almost exclusively on law's superstructure and is similar to Weinrib, see Richard W Wright, “Substantive Corrective Justice” (1992) 77:2 Iowa L Rev 625 at 665-82 [Wright, “Substantive”]. I will concentrate on Weinrib's account when discussing formalistic CJ. 
Weinrib's exposition is nuanced and highly abstract. ${ }^{75}$ It consists of three mutually supporting ideas: (1) formalism, (2) Aristotelian corrective justice, and (3) Kantian right. ${ }^{76}$

Weinrib’s account is expressly formalistic. He purports to explain the essential structural features that constitute the juridical relationship reflected in tort doctrine. ${ }^{77} \mathrm{His}$ aim is to "bring to the surface ideas that are latent in liability as a normative practice." basic features are the bipolar procedure that links $\mathrm{C}$ and $\mathrm{D}$, and the bipolarity of causation. ${ }^{79}$ The former refers to the fact that in tort litigation the "plaintiff sues the defendant and, if successful, is entitled to the defendant's performance of a remedial act”; and the latter reflects the requirement that the $\mathrm{D}$ must have actually caused the harm the plaintiff complains about. ${ }^{80}$ These core features reveal that tort law is a bipolar mode of legal ordering, the sole purpose of which is to do justice between the parties. ${ }^{81}$ The logic of tort law is thus the logic or "special morality" that applies equally and exclusively to these two parties simultaneously. ${ }^{82}$

Two points follow from this. First, because tort law is concerned only with doing justice between the parties in their bipolar dispute, there is no place in tort doctrine (or theory) for instrumentalist considerations, such as deterrence or promoting general welfare. ${ }^{83}$ Such considerations would advance policies outside the particular juridical relationship, and are thus logically unrelated to remedying the injustice arising consequent to the doing and suffering of harm within this relationship. ${ }^{84}$ Second, tort law's exclusive focus on correcting injustice between the parties means it can only be understood from its own internal "immanent perspective" and evaluated solely by considering the extent to which it coherently pursues this single goal. ${ }^{85}$ The adequacy of tort law cannot be measured against (and hence it is itself unresponsive to) external ideas about morality or any utilitarian criteria - it is good or bad based solely on how well it pursues interparty justice. These points underpin Weinrib’s express formalism, which is encapsulated in the following passage:

In tort law properly understood, the doing and suffering of harm constitutes a normative unit that matches the bipolar procedure of tort recovery. Tort law does not forward independently justified goals. Rather, it gives juridical expression to the coherence of this normative unit. When tort law reflects and elaborates the intrinsic ordering of its basic structure, tort law has the only purpose it can coherently have: to be tort law. ${ }^{86}$

Consequently, a thorough engagement with this work is not possible in the scope of this article. This discussion is limited to its main points.

Weinrib, Idea, supra note 45 at 18-19.

See ibid at 46; Weinrib, "Personality," supra note 74 at 113-14.

Weinrib, "Personality," ibid at 114.

Ernest J Weinrib, “Understanding Tort Law” (1989) 23:3 Val U L Rev 485 at 494 [Weinrib, "Understanding”].

Ibid.

See Weinrib, Idea, supra note 45 at 63-66, especially ch 5.

Ernest Weinrib, “The Special Morality of Tort Law” (1989) 34:3 McGill LJ 403 [Weinrib, “Morality”] ("[t]ort law is characteristically concerned with the defendant's doing and the plaintiff's suffering the same harm. The special morality of tort law, accordingly, is the morality that pertains to this relationship of doer and sufferer" at 407-408).

Weinrib, Idea, supra note 45 at 72-75.

Ibid ("welfare cannot supply the normative underpinning for private law because private law relationships are bipolar and welfare is not. Whatever its normative appeal, welfare does not connect the doer to the sufferer of harm” at 133).

Ibid at 114 .

Weinrib, “Understanding,” supra note 79 at 525-26; cf Weinrib, Idea, supra note 45, ch 2. 
So far we have seen that Weinrib's formalism is largely negative in that it is aimed at rejecting instrumentalist or ethical explanations and evaluations of tort doctrine. ${ }^{87}$ Weinrib's next task is to elucidate his positive account of tort's "justificatory structure" by reference to the principles of interparty justice that characterize tort law's "special morality." ${ }^{\text {" }}$ "The first part of this answer lies in Aristotle's theory of corrective justice, which Weinrib contrasts with distributive justice (DJ). Both forms of justice relate to each person's "equality of holdings.” Under DJ, holdings (i.e. rights, benefits, and burdens) are distributed throughout society based on identifiable criteria (such as virtue or need). Under DJ, the "greater a particular party's merit under the criterion of distribution, the larger the party's share in the thing being distributed." ${ }^{89}$ Injustice arises where one receives less (i.e. an unequal amount) than he is are entitled to under this criterion, so that if virtue is the standard, it is unjust for a bad man to receive more than a good one; and if need is the standard, equality is violated (and a DJ claim arises) if a rich man receives more than a poor one.

$\mathrm{CJ}$, in contrast, is "transactional" rather than "distributional." $90 \mathrm{CJ}$ is concerned with correcting disturbances caused to each person's equality of holdings. ${ }^{91}$ A simple example is where $\mathrm{X}$ has stolen property from $\mathrm{Y}$, resulting in the former having more and the latter less than she is entitled to. In Weinribian parlance, $X$ has made a factual gain that correlates with Y's factual loss. However, in order to fit all tort doctrine into this pattern, Weinrib argues that "gain" and "loss” must be understood "normatively" not factually. A normative gain occurs where $\mathrm{X}$ has transgressed a legal norm — in doing so he has acquired more than he should because he exercised his will in a manner prohibited by law; and a normative loss refers to Y having less than she should because she has suffered a violation of her legal rights. ${ }^{92}$ So, a punch on the nose fits this pattern because it results in a normative gain to the puncher and a normative loss to the victim. And these gains and losses "correlate” since they arise from the same injustice. At this point, CJ steps in (as the special morality guiding the tort of battery) requiring the defendant to compensate the claimant, thus shifting this loss back and restoring the equality that existed prior to the bipolar transaction (i.e. punch) which disturbed it. ${ }^{93}$ Importantly, CJ is understood formalistically, so that its (and hence tort's) conception of "injustice” is judged solely by reference to whether a transactional disturbance occurred; it is unconcerned with independent moral or utilitarian ideas when viewing such disturbances as "unjust." 94

Thus far, Weinrib's account explains the relational link between claimant and defendant and explains the object of tort law (as an instantiation of $\mathrm{CJ}$ ) as restoring the parties to their pre-disturbance equality of holdings. However, it leaves us wondering what this equality of holdings consists of. Since the "wrongs" of tort (under CJ) are acts (the doing and suffering of harm, resulting in normative gains and losses) that disturb the parties' equality of

See Robert L Rabin, “Law for Law’s Sake,” Book Review of The Idea of Private Law by Ernest J Weinrib, (1996) 105:8 Yale LJ 2261 at 2264.

Weinrib, Idea, supra note 45 at 57.

Ibid at 62 .

Ibid at 61 .

Ibid at 61-2.

See ibid, ch 5, especially at 115-120 (transactions that breach legal norms (i.e. torts) yield a "normative surplus for the defendant and a normative deficit for the plaintiff” at 119).

See ibid at 134-36.

Ibid at 76-80. 
holdings, ${ }^{95}$ we cannot understand or give content to these wrongs until we appreciate the nature of this "equality." ${ }^{\text {"W }}$ Weinrib acknowledges this, and argues that Aristotle's exposition of CJ leaves this question largely unanswered. ${ }^{97}$ To explain the nature of this equality, and provide normative content to the rights and correlative duties of tort law (and thus to determine at the most abstract level which principle makes conduct unjust and hence wrong in tort law), Weinrib deploys the third branch of his theory, Kantian right. ${ }^{98}$ This principle of "right" dictates that the "free choice of the one must be capable of coexisting with the freedom of the other." 99 Put differently: "[t]he equality of corrective justice ... [is] the equality of free wills in their impingements on one another. In the Kantian view, such equality is normative because it reflects the normativeness intrinsic to all self-determining activity." ${ }^{100}$ Kantian right "allows one to trace corrective justice back to its normative roots in self-determining agency and forward to the values ... of a coherent legal order." ${ }^{\text {101 }}$ It "requires that each actor treat the other's personal ... embodiments in a manner that does not violate their formal equality as free wills." 102

Importantly, Weinrib’s conception of Kantian right, like his conception of Aristotelian CJ, is imbued with formalism. Thus, Kantian right is not concerned with the morality of a particular action; hence it is not violated by (and will not deem wrongful) acts that contravene principles of Kantian ethics, including the supreme moral imperative to treat people as ends, not means. ${ }^{103}$ Rather, it is concerned only with the outward manifestation of free wills, and it commands nothing more than each person refrain from acting in a manner that prevents others from exercising free choice. How one exercises this choice is an internal matter, the "goodness" of which is a matter of ethics; but the right of each person to have the capacity to act as a chooser (i.e. to be able to externalize his internal desires) is a public matter, and Kantian right (in its formalistic sense) is violated where the free will of one person overwhelms the capacity of another person to manifest his will. ${ }^{104}$ This narrow principle of Kantian right lies at the root of all torts; it "organizes them," at the most abstract level, "by exhibiting the content of rights and duties as expressive of the capacity for purposiveness [i.e. the ability to externalize one’s will] that they presuppose.”105

Ostensibly, Weinrib's theory is of limited utility for fitting invasion of privacy into the normative foundations of tort law. Because his formalistic conception of Kantian right is divorced from Kantian ethics, arguments in support of the dignity basis for privacy are irrelevant. Likewise, Weinrib's formalistic conception of CJ means that instrumentalist arguments are also irrelevant. Consequently, his theory purports to exclude from

Ibid at 78.

See Rabin, supra note 87 (noting at this stage we are "left with form without content" since we do not know what acts violate equality at 2264).

See Weinrib, Idea, supra note 45 at 76-83.

For Weinrib's argument why the equality to which CJ restores the parties cannot be simply the holdings they had under the relevant DJ regime (because this would sneak moral- and utility-based arguments into CJ, which Weinrib’s formalism rejects), see Weinrib, Idea, ibid at 76-80.

Ibid at 104.

Ibid at 84.

Ibid at 114.

Ibid at 104.

See ibid, ch 4, especially at 99, 109-13. Weinrib takes this formalistic view of Kantian right because he reads Kant as proposing a separation between the duties of law and ethics.

Ibid at 98-99, 104-13.

Weinrib, "Personality,” supra note 74 at 123; Weinrib’s recent work employs different terminology. "Kantian right" is now referred to as "personality" but the concepts are the same (see ibid at 1245, n 14). 
consideration two of the most powerful clusters of arguments typically offered in favour of creating a privacy tort. ${ }^{106}$

Nevertheless, invasion of privacy can be justified as a tortious wrong in Weinrib's paradigm. We can appeal — quite straightforwardly, in fact — to his formalistic conception of Kantian right. As discussed at the outset of this paper, privacy is intimately connected to autonomy and, through autonomy, to the idea of personhood. Compelled disclosures of private information quite obviously overwhelm the victim's choice to keep something private, and thereby overwhelm his autonomy inasmuch as they force him to reveal aspects of himself involuntarily. ${ }^{107}$ Moreover, recall that covert watching undermines the subject's capacity to exercise an autonomous choice about self-presentation; ${ }^{108}$ and overt watching may produce conformity, thus stifling the victim's freedom to externalize his will. Insofar as privacy invasions undermine the esteem with which a man holds himself as a moral actor (such esteem being a precondition to personhood), they can have the insidious effect of undermining his capacity to exercise autonomous choice in the future. In light of these points, Lord Justice Sedley's statement in Douglas that tort law can "recognise privacy itself as a legal principle drawn from the fundamental value of personal autonomy" 109 fits squarely with Weinrib's conception of Kantian right as the "basis of the rights that mark out a sphere that others must treat as inviolate."110 With privacy thus anchored in Weinrib's conception of Kantian right, the rest of the analysis is straightforward. In Weinribian parlance, D's invasion of C's privacy constitutes the "doing” of harm that results in C's "suffering” of the same, which in turn gives rise to a normative "gain” which correlates to a "loss." This doing and suffering of harm forges the juridical link between the parties. CJ may then step in and remedy this. ${ }^{111}$

Although Weinrib's formalistic emphasis has been the subject of academic criticism, ${ }^{112}$ the broad strokes of his theory are reflected in the work of other important commentators. Arthur Ripstein, for example, has developed a sophisticated theory based on "reciprocity,"113 which he argues expresses the idea of balancing a claimant's interests in security against a defendant's interests in liberty of action which underlies all torts. In striking this balance, and in drawing the line between "appropriate and inappropriate" conduct, tort law responds to the principle of "equal freedom,” meaning: “[a]ll are allowed an equal liberty to pursue their ends, subject to the requirement that they not interfere with the ability of others to pursue

See Part II, above, noting the deontological and consequentialist values underpinning privacy.

Cf Brown, "Privacy," supra note 13 (justifying invasions of privacy in tort doctrine on this basis at 607).

Benn, supra note 30 ("[c]overt observation ... is objectionable because it deliberately deceives a person about his world, thwarting, for reasons that cannot be his reasons, his attempts to make a rational choice" at 10 [emphasis in original]).

Douglas, supra note 10.

Weinrib, "Personality," supra note 74 ("[i]njustice occurs when what one person ... does is inconsistent with another person's rights" at 123).

Brown, "Privacy," supra note 13 (applying CJ to privacy in this way at 604-605).

See generally: Rabin, supra note 87; Wright, "Substantive," supra note 74; Benjamin C Zipursky, "Pragmatic Conceptualism" (2000) 6:4 Leg Theory 457 at 467-70 [Zipursky, "Pragmatic"]. The criticisms are numerous and complex; consequently, a detailed discussion of them is beyond the scope of this thesis.

See generally Arthur Ripstein, Equality, Responsibility, and the Law (Cambridge: Cambridge University Press, 1999) [Ripstein, Equality]. Weinrib interprets Ripstein's work as being substantively identical to his own: Weinrib, "Personality," supra note 74 (noting Ripstein’s work is "essentially the same” as at 141 , and it is "completely in accord with — and, indeed, largely replicate[s]" his own work at 143). 
theirs." ${ }^{114}$ Crucially, Ripstein asserts that in deciding which interests to protect in the first place, tort law is concerned, most fundamentally, with the importance an interest has to the leading of an autonomous life. ${ }^{115}$

One final point should be emphasized. Weinrib notes that because the rights and correlative duties of CJ operate in the world of human interaction, and serve to constrain human behaviour, the content of these rights and duties (as reflected in tort doctrine) must (and do) take their shape from the shared "social meanings" within a particular society. ${ }^{116}$ Other formalistic corrective justice scholars, such as Ripstein ${ }^{117}$ and Jules Coleman, ${ }^{118}$ make similar points. This is important for the development of any privacy tort since the concept of privacy itself is guided by social norms. ${ }^{119}$ By making allowance for such norms in tort doctrine, Weinrib's theory is thus particularly amenable to protecting privacy, notwithstanding his refusal to consider ethical dignity and utility-based arguments in support thereof.

\section{SubStantive CorRective JusticE}

Richard Wright argues Weinrib's formalistic insistence that ethical considerations be excluded from tort doctrine is based on a misreading of both Aristotle and Kant. Wright elucidates this alleged misreading, and posits what he calls substantive corrective justice. His aim is to save CJ from Weinrib’s "formalistic evisceration" by anchoring it in "fundamental principles of morality."120 Wright's argument is important for our purposes because it grounds CJ in Kantian ethics. Thus, we may appeal to the Kantian ethical imperative to treat people as ends in themselves as a fundamental principle lying at the root of tort law.

Before explaining Wright's argument, one caveat is apposite. Wright's discussion of Aristotle and Kant, and his criticism of Weinrib's interpretation of the same, is lengthy and complex. I will not conclude which interpretation is correct, for reasons of space. Besides, whichever reading is correct is beside the point I am trying to make, which is that a civil claim for invasion of privacy fits within the conceptual structure of tort law as set out by various important tort theorists (Wright being one of them). ${ }^{121}$

Arthur Ripstein, "Philosophy of Tort Law" in The Oxford Handbook of Jurisprudence and Philosophy of Law, Jules Coleman \& Scott Shapiro, eds, (Oxford: Oxford University Press, 2002) 656 at 663 [Ripstein, "Philosophy"] [emphasis added].

Ripstein, Equality, supra note 113 at 50, 55, 268-69. Cf Stephen R Perry, "The Moral Foundations of Tort Law" (1992) 77:2 Iowa L Rev 449 (emphasizing "personal autonomy" is the most "fundamental human interest" protected in the law of torts at 498, and respect for autonomy is the touchstone for determining which 'rights' torts will protect by imposing correlative duties of non-interference at 496512).

116 Weinrib, Idea, supra note 45 at 104.

117 Ripstein, "Philosophy," supra note 114 at 663.

118 Coleman, Principle, supra note 74 at 62, 69; see also Goldberg \& Zipursky, supra note 45 (arguing many torts are “definitionally connected to social norms” at 984).

Several scholars have emphasized that social norms, which reflect our shared intuitions, help us identify what is private at both a conceptual and a legal level. See Thomas Scanlon, "Thomson on Privacy" (1975) 4:4 Philosophy \& Public Affairs 315 at 316; Post, "Community," supra note 73 at 968-69; Parent, supra note 16 at 307.

120 Wright, "Substantive," supra note 74 at 629.

121 See also Stevens, "Other," supra note 48 (noting one can accept a tort theory deriving from Kantian philosophy "without having to swallow Kant down holus bolus" at 31). 
Wright's argument, as it pertains to Aristotle, advances in two stages. First, he asserts that, contrary to Weinrib's reading, Aristotle was not a formalist. In other words, he did not believe that law can only be understood from within, according to its own "immanent rationality," nor that it is divorced from ethics such that it has no purpose other than "to be itself.”" ${ }^{122}$ Rather, Wright says Aristotle was a "principlist.” ${ }^{123}$ By this, Wright means Aristotle viewed law as the "instrument by which politics seeks to assure that each citizen is completely virtuous, and justice is the manifestation of that complete virtue in citizens' relations with one another." 124 Consequently, Aristotle must have thought law should be responsive to principles of natural justice, which are imbued with morality. ${ }^{125}$ Wright says Aristotle appreciated that law is always imperfect and that courts must "fill in the details or gaps” by having recourse to fundamental moral principles. ${ }^{126}$

Second, Wright elucidates Aristotle's account of CJ and endorses it as the explanatory superstructure of tort doctrine. Wright's discussion here is consistent with Weinrib's, so that DJ refers to one's equal entitlement under the relevant distributional criteria, whereas CJ is a form of transactional justice designed to remedy disturbances to equality which result in gains and losses flowing from the doing and suffering of harm. Furthermore, like Weinrib, he emphasizes that to understand which acts are wrongful disturbances to equality, we must know what this equality consists of. ${ }^{127}$

Where Wright differs from Weinrib is that he believes Aristotle's notion of the equality to which CJ restores the parties can be deduced if we reflect on Aristotle's views about the interrelationship between law and morality, and consider also the criteria that are not relevant to CJ. Regarding the latter point, Wright emphasizes Aristotle was clear that DJ and CJ are distinct types of justice; and he was also clear that whereas equal entitlement under DJ refers to the relevant distributional criteria, the equality of CJ does not. Thus, according to Aristotle:

[T] he justice in transactions [i.e. transactional $\mathrm{CJ}$ ] is a sort of equality ... and the injustice a sort of inequality.... [But for CJ] it makes no difference whether a good man has defrauded a bad man or a bad man a good one;... the law looks only to the distinctive character of the injury, and treats the parties as equal, if one is in the wrong and the other is being wronged, and if one inflicted injury and the other has received it. ${ }^{128}$

For Wright, this passage shows that CJ is completely unconcerned with the parties' comparative pre-transactional virtue - it does not look to any "interpersonal comparisons or rankings” when assessing what each person's equal share ought to be. ${ }^{129}$ Consequently,

\footnotetext{
122 Wright, “Substantive,” supra note 74 at 634, 686.

Ibid at 630, 686.

Ibid at 686 .

Ibid at 686-87.

Ibid.

Ibid at 695-700. Wright at 693-94 also argues, like Weinrib, that this equality cannot simply be the predisturbance holdings as determined by the DJ criteria.

128 Aristotle, "Nichomachean Ethics," translated by WD Ross \& JO Urmson in Jonathan Barnes, ed, The Complete Works of Aristotle: The Revised Oxford Translation, vol 2 (Princeton: Princeton University Press, 1984) 1729 at 1786 quoted in ibid at 692 (this is the only time Aristotle elucidates what is meant by equality under CJ).

129 Wright, "Substantive," ibid at 700-702 . Consequently, all utility based arguments such as general public
} welfare or efficiency are excluded from Aristotle's account of CJ. 
equality under CJ must mean that the parties be treated as absolute equals. ${ }^{130}$ Importantly, in Wright's view, treating people this way is not (as Weinrib says) limited to simply respecting each person's capacity to act as a "chooser"; ${ }^{131}$ rather, it must refer to the "absolute moral worth" of each person, ${ }^{132}$ and this moral worth must be understood to "prefigure ... through ethical presuppositions" the Kantian ethic of treating people as ends and not means. ${ }^{133}$ This substantive ethical understanding of equality must lie at the core of CJ because Aristotle's principlism regards law as an instrument of politics, and politics as aimed at perfecting virtue in society. Thus, Wright states of Aristotle:

The goal of politics and justice is the attainment of this common good [the full realization of one's humanity

... in accord with complete virtue over one's life] for each and every citizen of the state, which he describes as a community of free and equal individuals.

Since justice is concerned with the attainment of the good, the absolute equality of the parties in corrective justice must be conceived as an absolute moral equality. ${ }^{134}$

In sum, Wright views $\mathrm{CJ}$ as the superstructure which explains the operation of tort doctrine, and for him it must be understood as having at its core a "powerful ... substantive ethical content," which responds to gains and losses flowing from disturbances to equality which arise from acts that are "inconsistent with the absolute moral equality of the parties to the interaction.”135

As mentioned, Wright also devotes considerable space to refuting Weinrib's reading of Kant. ${ }^{136}$ This discussion is lengthy and esoteric. Essentially, the difference between these authors is this: Weinrib reads Kant as postulating a disjunction between law and ethics, whereas Wright interprets Kant as intermixing the two. Thus, for Weinrib, law is prior to ethics, and the wrongs of tort (i.e. unjust disturbances to equality) are assessed without considering the (un)ethical nature of the acts themselves. ${ }^{137}$ This accounts for Weinrib's thin version of Kantian right, which is concerned only with acts that undermine one's capacity to act as a chooser. For Wright, ethics is prior to law, and the wrongs of tort are influenced by the Kantian morality that provides the normative backdrop to private law. ${ }^{138}$ Thus, for Wright, the principle of Kantian right underpinning the wrongs of tort is responsive to the ethical requirement that people treat others as ends, not means. ${ }^{139}$

The importance of Wright's argument for our purposes is that by grounding CJ (and hence tort law) in Kantian ethics, it makes room for considering the moral imperative to treat people as ends in themselves. It is thus able to accommodate dignity arguments advanced in support

Ibid at 701.

See discussion of Weinrib in Part III.C, above.

Wright, "Substantive," supra note 74 at 702.

Ibid.

Ibid at 701-702.

Ibid at 702 .

Ibid at 644-64.

See Weinrib, Idea, supra note 45, ch 4, especially at 109-13.

See Wright, “Substantive,” supra note 74 at 651-53, 657, 661.

Ibid at 661 . 
of privacy within CJ's conceptual account of tort law. Such arguments, we have seen at the outset of this paper, have been advanced by many privacy theorists. Moreover, they resonated with the House of Lords in Campbell. Lord Hoffmann, for instance, stressed the importance of privacy in terms of the "protection of human autonomy and dignity," which for him included the "right to the esteem and respect of other people.""140

\title{
E. TORTS AS Rights, TORTS AS WRONGS
}

\author{
Robert Stevens proposes a "rights model"141 explaining all of tort law. ${ }^{142}$ According to \\ Stevens:
}

A tort is a species of wrong. A wrong is a breach of a duty owed to someone else. A breach of a duty owed to someone else is an infringement of a right they have against the tortfeaser. Before a defendant can be characterized as a tortfeasor the anterior question of whether the claimant had a right against him must be answered. The law of torts is concerned with the secondary obligations generated by the infringement of primary rights. ${ }^{143}$

Thus, the tort of battery reflects our primary right to bodily integrity, which correlates with a duty on others not to touch us without our permission; and the tort of defamation imposes duties on others not to spread untruths about us, because we have primary rights of reputation. ${ }^{144}$ The breach of these duties infringes our primary rights, thereby generating secondary rights and duties which typically take the form of the defendant's obligation to pay compensation. $^{145}$

While Stevens' account is broadly consistent with various CJ theories — which also invoke the language of rights and correlative duties as the structure of tort relationships ${ }^{146}$ his approach is at once broader and more practical in two important respects. First, contrary to Weinrib, Stevens asserts that just because rights correlate with duties (and hence tort law is fundamentally concerned with doing interparty justice in bipolar disputes), it is wrong to think that courts do not consider factors outside the litigant relationship when determining the scope of rights and applicable defences. ${ }^{147}$ This is important for an informational privacy tort, since balancing the defendant's expression interest against the claimant's right to privacy will necessarily require evaluating the overall public interest value of the speech.

140 Campbell, supra note 2 at para 51 [emphasis added].

141 Stevens, Torts, supra note 44 at 2; see also Stevens, “Other,” supra note 48.

142 See e.g. Brown, “Ambition,” supra note 60 at $114-15$. Perhaps the most important contribution of Stevens' book is his detailed application of this paradigm to all of the key doctrinal features existing in tort doctrine, which is something no rights-based theorist had previously attempted. For reasons of space, I cannot discuss in detail Stevens' application of his theory, just as I could not discuss Weinrib's. An outline will have to suffice.

143 Stevens, Torts, supra note 44 at 2 [footnotes omitted].

144 Ibid at 5-8. Stevens identifies rights of reputation, rights of bodily safety and freedom, and rights of property as our core rights (ibid at 5, citing Allen v Flood, [1898] 1 AC 1 at 29 (HL)). The list of claim rights we already have extends beyond these three (see ibid, ch 2 for a list); and the claim rights recognized in law is not closed (ibid at 315).

$145 \quad$ Ibid at 287.

146 See Weinrib, Idea, supra note 45 at 76; see also Weinrib, “Morality,” supra note 82 at 404-405.

147 Stevens, Torts, supra note 44 ("[I]n defining the scope of our primary rights the courts do take into account the general social benefit to everyone of an activity and the risks to everyone not just the claimant, which it poses. Ambulances are allowed to drive faster than delivery vans, although the risk they pose to a bystander is precisely the same” at 328 [emphasis in original]). 
Second, like Wright, Stevens imbues the rights recognized in tort with substantive moral content; but unlike Wright, Stevens does not tie his account to a close reading of Aristotle and Kant. Rather, Stevens asserts that to understand why we have the (common law) rights we have one need only look to the principles of practical morality evident upon "human reflection" about the "nature and experience of ourselves, and the world and society in which we live." "The "minimum content" of these moral rights, from which all common law torts derive $^{149}$ and take their shape, ${ }^{150}$ is anchored in the "golden rule," which Stevens says requires people to "respect the choices and preferences of others. It requires that we treat others as if we were them, not as if they were us.... One further aspect of the golden rule is that we are each deserving, prima facie, of equal concern and respect." ${ }^{\text {"151 }}$ In general, "the judicially created private rights at common law, which give legal force to our moral rights, are concerned with maximizing the autonomy of each of us by enabling the greatest respect for one another, and how each of us chooses to live our lives." ${ }^{\text {„152 }}$

Stevens' approach to the moral foundations of tort law has both practical ${ }^{153}$ and historical $^{154}$ attraction, and it enables us to appeal to the various dignity arguments offered in favour of privacy when anchoring a civil claim for the same within the law of tort without having to referee the Wright-Weinrib debate over the "correct” reading of Aristotle and Kant. All of this is for the good and makes his approach very normatively amenable to privacy claims. $^{155}$

Furthermore, the structural amenability of Stevens' approach to a civil claim for invasion of privacy is evidenced in three ways. ${ }^{156}$ First, although Stevens does not discuss privacy in any detail, there is no doubt he would accept that the wrongful disclosure of private information fits within his structural account of tort law. Under the heading "How to Write a Torts Textbook" he lists "Private Information" as being among the "primary rights which we have which are capable of being infringed so as to give rise to secondary obligations."157 Second, the straightforward applicability of Stevens' theory to a civil claim for invasion of privacy is borne out in the analysis of the House of Lords in Campbell. ${ }^{158}$ The tabloid's invasion of Campbell's privacy was “wrong,” and remedial relief was available, not because

Stevens, Torts, ibid, at 330-31.

Ibid at 331-32.

Ibid at 337.

Ibid at 332.

Ibid at 339; cf Stevens, “Other,” supra note 48 (contrasting golden rule and Kantian ethical imperative to treat people as ends at 28-34).

Stevens, Torts, ibid ("it is very doubtful whether those responsible for the common law, judges, either could have been or were familiar with the work of [Kantian or Aristotelian] philosoph[y]" at 329).

Ibid at 330, quoting J Ibbetson, "Natural Law and Common Law” (2001) 5:1 Ed L Rev 4 ("[i]t would not be too much of an exaggeration to say that the classical Common Law of the nineteenth and twentieth centuries was really a product of the eighteenth-century Natural Law tradition” at 6); $c f$ Stevens, "Other," supra note 48 ("Lord Atkin also thought the entire law of torts was best explained in terms of the Golden Rule” at 34). Notably, the first American cases to recognize a privacy tort expressly relied on principles of natural law. See Pavesich v New England Life Insurance Co, 50 SE 68 (Ga 1905) ("[t]he right of privacy has its foundation in the instincts of nature ... [and] is therefore derived from natural law” at 69-70).

By "normative" I mean we can say that privacy fits within the normative, ethical foundations of the rights protected by the law of torts as posited by Stevens. For a discussion of how invasions of privacy offend dignity and autonomy, and fail to show proper respect for people, see Part II, above.

By "structural” I mean the pattern of reasoning evidenced in actual adjudication, so that torts are wrongs in the sense that they violate rights.

Stevens, Torts, supra note 44 at 303.

Campbell, supra note 2. 
of any loss caused to Campbell (since the claim was actionable per se), nor because of an unconscionable abuse of a relationship of confidence (since this traditional requirement of confidence was dispensed with), but rather because Campbell had a right to privacy, which imposed a corresponding duty of non-interference on the tabloid. By basing liability solely on the defendant's invasion of the claimant's right, Campbell represents a paradigmatic example of Stevens' approach in action. ${ }^{159}$ Third, it is worth noting that Samuel Warren and Louis Brandeis' seminal article, ${ }^{160}$ which gave birth to the American privacy tort, was grounded in a rights-based understanding of tort law. This is evident not just in the title of the article itself ("The Right To Privacy"), but also in the authors' reliance on the phrase "the right to be let alone," which came from Justice Cooley's influential Treatise on the Law of Torts which classified all torts according to the rights they protected. ${ }^{161}$ The American privacy torts continue to reflect this rights-based conception of tort law. ${ }^{162}$

Stevens' approach not only has nineteenth century antecedents (principally in the texts of Cooley and Addison); ${ }^{163}$ it is also reflected in the contemporary writings of Benjamin Zipursky and John Goldberg, who develop an account of torts as "wrongs." ${ }^{164}$ Although these latter authors concentrate on "wrongs," rather than "rights," their structural account is substantively the same as Stevens’ — it just proceeds from the opposite direction:

[T] ort law identifies and enjoins actions that constitute mistreatments of others. In turn, it identifies and confers on each of us a set of rights not to be mistreated. When one of these directives is violated - when a tort is committed - the victim of the mistreatment not only has suffered a setback in the eyes of the law but is also recognized as having a legitimate grievance against the wrongdoer. The defendant has violated her legal rights and that violation entitles her to a remedy against the wrongdoer. ${ }^{165}$

Since this structural account of tort law (organized, as it is, around correlative rights and duties) is basically the same as Stevens', it follows that a civil claim for invasion of privacy fits easily within it for the reasons discussed immediately above in relation to Stevens' account. Indeed, Zipursky expressly fits the American privacy torts into his scheme. ${ }^{166}$ Furthermore, like Stevens, these authors assert that the existence and scope of the rights protected by tort law derives from normative principles of practical morality. ${ }^{167}$ Accordingly, their account, like Stevens, makes room for marshalling the various dignity arguments

Of course, this is equally true where, instead of basing the claim as a modified breach of confidence action, the court instead grounds it expressly in a common law right to privacy protected by tort law, which is how the claim was analyzed recently by the Ontario Court of Appeal in Jones, supra note 5 at para 65.

Samuel D Warren \& Louis D Brandeis, “The Right to Privacy” (1890) 4:5 Harv L Rev 193. See Leebron, supra note 64 at 781 ("[t]here can be little doubt that Warren and Brandeis adopted the rights-based paradigm” of tort law at 785-86).

See ibid; Benjamin C Zipursky, "Rights, Wrongs, and Recourse in the Law of Torts" (1998) 51:1 Vand L Rev 1 [Zipursky, "Rights"] (anchoring American privacy torts in his theory of "torts as rights and wrongs” at 90, which is, as I discuss immediately below, substantively identical to Stevens' theory). Cooley, supra note 64; Horace Smith, ed, Addison on Torts, 6th ed (London: Stevens and Sons, 1887). For a discussion of the rights-based emphasis and organization of these early texts, see Leebron, supra note 64 at 782; Stevens, Torts, supra note 44 at 296. Glanville Williams has also presented tort law as being "axiomatic[ally]" about rights and their correlative wrongs: Glanville L Williams, "The Foundations of Tortious Liability” (1939) 7:1 Cambridge LJ 111 at 116. Goldberg \& Zipursky, supra note 45.

Ibid at 973; see additionally at 981, n 294: this is to say the same thing as "conceptualising tort law as conferring a right against injury and a corresponding duty not to injure." See also Zipursky, "Rights," supra note 162 at $5,87$. 
offered in support of privacy. Moreover, they emphasize, and Stevens would likely agree, that in ascertaining these moral principles, judges are guided by the norms existing in society. ${ }^{168}$ As mentioned above, this is important for any privacy tort, since the concept of privacy itself is very much guided by social norms.

However, Zipursky goes further than Stevens in one important respect. Stevens limits the source of judicially created rights to principles of practical morality. He rejects bolstering the moral basis of legal rights with consequentialist arguments pointing to the various beneficial effects (to individuals and to society) that recognizing a new right may have. ${ }^{169}$ In contrast, Zipursky makes room for wider "political” considerations when looking to why we have the rights we have. ${ }^{170}$ For Zipursky, it is simply the case that a "large part of what judges do in common-law cases" is to "create" the law, and in doing so they often draw upon consequentialist considerations to bolster deontological ones. ${ }^{171}$ Insofar as privacy is concerned, it would appear that Zipursky's view better reflects actual judicial decisions. ${ }^{172}$ The New Zealand Court of Appeal, for instance, bolstered its deontological justifications for creating a privacy tort with the observation that respect for privacy is essential to the "wellbeing of all human beings." ${ }^{173}$ The same point was recently made by Justice Sharpe, in the Ontario Court of Appeal, ${ }^{174}$ and by Lord Nicholls in the House of Lords. ${ }^{175}$ The European Court of Human Rights has also emphasized the functional importance of privacy, noting that protecting privacy is "primarily intended to ensure the development, without outside interference, of the personality of each individual in his relations with other[s].”176

Goldberg \& Zipursky, ibid (speaking of wrongs in terms of the "positive morality of the community," and arguing this explains why certain wrongs have become torts in the first place). Later, Goldberg and Zipursky assert the content of torts is influenced by moral norms, noting "[torts] track social norms of acceptable and unacceptable conduct" (ibid at 983). Cf Zipursky, "Rights," supra note 162 (referring to common law rights stemming from "norms of social conduct" at 92, n 299 citing John CP Goldberg, "Community and the Common Law Judge: Reconstructing Cardozo's Theoretical Writings" (1990) 65:5 NYUL Rev 1324, 1334-36); cf Stevens, Torts, supra note 44 (principles of morality he refers to are "capable of being deduced from the nature and experience of ourselves, and the world and society in which we live" at 330). This suggests his golden rule is somewhat socially determined). Stevens, Torts, ibid at 332-36. Stevens argues consequentialist arguments are (1) unnecessary (since the golden rule has its own pre-emptive force), (2) dangerous (since they permit rights to be overridden), and (3) inappropriate (since judges lack the legitimacy to make "policy" decisions). While a full discussion of these points is beyond the scope of this thesis, I should say that I do not find them particularly convincing. Just because moral rights are self justifying does not mean courts should blind themselves to the beneficial consequences that flow from their recognition. This is doubly true since, practically speaking, judges are aware that their decisions have real-world consequences both for the parties and for all future litigants, a point I discuss in further detail in the following section. Regarding (2), we know that many rights are in fact overridden for instrumentalist reasons, as in defamation law where rights to reputation are qualified where the publication is of sufficient public interest and the defendant acted responsibly (see e.g. Cane, Anatomy, supra note 45 at 135). As to (3), it seems unlikely that "policy" questions can be divorced entirely from "principled" ones. Zipursky, "Rights,” supra note 162 at 92; cf Zipursky, "Pragmatic,” supra note 112 at 477. Zipursky, "Pragmatic," ibid at 477.

See The Hon Justice IDF Callinan, "Privacy, Confidence, Celebrity and Spectacle” (2007) 7:1 OUCLJ 1 (a Justice of the High Court of Australia, writing extra-judicially, justified creating a common law privacy tort not only to provide relief for distress suffered, but also the "improvement of social behaviour" at 10).

Hosking, supra note 4 at para 239.

Campbell, supra note 2 ("[a] proper degree of privacy is essential for the wellbeing and development of an individual" at para 12). 
The idea of fitting considerations of social utility into an essentially rights-based paradigm can be traced back to Richard Posner. ${ }^{177}$ Posner's concern was to reconcile various instrumentalist accounts of tort law with the ostensible non-instrumentalism of Aristotelian CJ. The problem Posner faced was this: CJ, as we have seen, is concerned with restoring the parties to their pre-transactional equality of holdings. Being characteristically bipolar, it eschews drawing on any considerations (including questions of social utility) lying outside the particular claimant-defendant relationship when determining what is 'just' as between the litigants. But, as we have seen, Aristotle did not go very far in explaining what the pretransactional equality consists of. Posner argued that it is here that various instrumentalist arguments are relevant. Put simply, such considerations help determine what rights we have in the first place; whereas $\mathrm{CJ}$ is remedial, and is concerned with the procedure of restoring parties to their pre-transactional equality (equality being determined in the first instance by instrumentalist considerations). ${ }^{178}$ The importance of this approach for our purposes is that it makes room, in Zipursky's rights-based conception of tort law, and in CJ theories more broadly, for judges to draw upon the various consequentialist arguments advanced in support of privacy when deciding to recognize a claim for the same within the law of torts. ${ }^{179}$

However, despite this limited reconciliation, it is important to note that this approach does not make room for considering consequentialist arguments when actually adjudicating the scope of civil claims. For this, we need to consider Cane's wider conception, set out below.

\section{F. TORTS AND RESPONSIBILITY}

Peter Cane has developed a sophisticated account of tort law as a "system of ethical rules and principles of personal responsibility for conduct." ${ }^{180}$ His approach has two broad aspects: (1) to account for the structure of tort law; and (2) to explain its normative functions and associated societal effects. There is considerable fluidity between these aspects, but I will discuss them separately.

Cane argues that all torts share the following three-part "anatomy”: (1) protected interests; (2) sanctioned conduct; and (3) sanctions. ${ }^{181}$ Before discussing these, two preliminary points are apposite. First, a central theme running through Cane's structural account is the idea of correlativity. As mentioned above, correlativity refers to the bipolarity of tort relationships, meaning each tort consists, most abstractly, of C's right which correlates with D's duty to respect that right. ${ }^{182}$ Cane argues that because of this correlativity, each of the three anatomical characteristics of torts must respond to the position of both C and D. ${ }^{183}$ Second,

Richard A Posner, “The Concept of Corrective Justice in Recent Theories of Tort Law” (1981) 10:1 J Leg Stud 187.

Ibid.

See Coleman, Principle, supra note 74 at 34-36. Coleman (himself a formalistic CJ advocate) has shown some receptiveness to Posner's idea of drawing upon various instrumentalist considerations as the background reasons explaining why we have the primary rights we have. Cane, Anatomy, supra note 45 at 1.

I will not discuss sanctions. It concerns remedial principles and hence falls outside the scope of this discussion.

Cane, Anatomy, supra note 45 at 12-14. Cane's concept of correlativity is not formalistic in the manner Weinrib's is. As explained below, this enables Cane to argue tort law must be responsive to wider goals of social welfare when creating and scoping rights.

Ibid at 13. (The bulk of his text, The Anatomy of Tort Law, is concerned with elucidating this). As with the above theorists, delving into the detail of Cane's 'proof' falls outside the scope of this article. 
correlativity highlights the fundamental ethical nature of tort law, more generally, as "a system of precepts about how people may, ought and ought not to behave in their dealings with others." ${ }^{\text {"184 }}$ In settling the bounds of acceptable conduct, tort law is concerned with striking a fair balance between the interests of victims and those of defendants - with calibrating "freedom from" injury with "freedom to" act as one chooses. ${ }^{185}$ Where, in light of this balancing, a court decides to impose liability, it is, in Cane's view, assigning ethically influenced legal "responsibility."186

Protected interests include “dignitary interests” (underpinning the right to one's reputation, protected in defamation), "physical interests" (protected in battery), and "property interests" (protected in trespass). ${ }^{187}$ "Interest" is essentially the same as the concept of "rights" in the theories discussed above, as they are the "object of positive protection in the form of the imposition of tort liability." "188 Interests take centre stage in Cane's account. ${ }^{189}$ Because of tort's correlative structure, however, Cane also uses interests in another sense, to refer to: (1) the countervailing private interests of alleged tortfeasors and, importantly, (2) public interests of society more generally. ${ }^{190}$ Countervailing private interests refer to the various interpersonal defences recognized in tort. ${ }^{191}$ Countervailing public interests refer to broad societal interests, such as liberty, freedom of speech, and the flow of information. ${ }^{192}$ Countervailing interests are "negative" in the sense of "setting the limits of tort liability."193

Cane's discussion of the second characteristic common to all torts (sanctioned conduct) is nuanced and complex. ${ }^{194}$ The key points, in brief, are as follows. Sanctioned conduct has two aspects. The first refers to the various standards of "fault" reflected throughout tort doctrine. Cane groups these into two broad categories, which reflect different ethical conceptions of responsibility. Strict liability is grounded in the ethical imperative to "compensate for adverse outcomes of the relevant activity," 195 whereas the standards of intent and negligence are anchored in the ethical imperative "not to engage in the liability attracting conduct." 196 Liability for the former is "a sort of tax on activities which attract such liability," whereas liability for the latter is a form of "penalty" which implies the law's "disapproval of the liability-attracting conduct." 197 Because of tort's correlative structure, Cane also considers sanctioned conduct from the claimant's perspective. Thus, tort law recognizes defences which relate to the conduct of undeserving claimants. This explains the doctrines

\footnotetext{
184 Ibid.

185 Ibid at 14-15. This mirrors Ripstein’s account, discussed in Part III.C, above.

186 Ibid.

$187 \quad$ Ibid at 67-79.

188 Ibid at 66 [emphasis added]. In subsequent works Cane speaks of rights and correlative duties, and the Weinribian language of "doing and suffering harm" to explain the structure of tortious responsibility: see e.g. Cane, Responsibility, supra note 45 at 196-97.

Cane, Anatomy, ibid (the "prime function of tort law is the protection and vindication of individual's interests” at 63). 
of contributory negligence and consent (or voluntary assumption of risk), ${ }^{198}$ which are grounded in ethical principles of correlative responsibility.

Having outlined Cane's structural account of tort law, I now turn to its normative functions and effects. Cane groups these into "intrinsic" and "extrinsic" functions. ${ }^{199}$ The former refers to "tort law as a set of ethical rules and principles of personal responsibility" organized around and expressed in the three part anatomy of doctrine discussed above. ${ }^{200}$ The primary intrinsic functions of adjudication are:

to provide guidance to individuals about how they may and ought to behave in their interactions with others, to provide protection for certain interests of individuals, to express disapproval of and to sanction certain types of conduct, to provide a means of resolving disputes between individuals and in this way to maintain social order and promote social cohesion. ${ }^{201}$

Importantly, like the rights-based theories discussed above, Cane grounds these ethical principles not in the esoteric learning of metaphysics, but in practical morality, which includes social norms of acceptable conduct. ${ }^{202}$ For Cane, such practical moral reasoning influences both the decision to protect a particular interest, and also aids in determining the prima facie scope and permissible limits of the same in light of the correlative interests of both parties to the dispute. ${ }^{203}$

Where Cane goes further than the above theorists is in his account of the extrinsic functions of tort law. These establish the prospective norms of responsible behaviour for society more generally. ${ }^{204}$ Courts rely upon various "policy considerations" (sometimes expressly, but more often implicitly) when deciding to create or refine the scope of rights and their corresponding duties. ${ }^{205}$ Such considerations reflect what Cane calls tort law's "forwardlooking functions." ${ }^{206}$ Practically speaking, judicial decisions to create, reject, or modify civil rights of action generate precedent. This has implications for society insofar as it changes the nature of everyone's rights and correlative duties in the future. In Cane's view, courts, being aware of this, must (and do) "have an eye on the role of tort law as public morality when resolving individual disputes.”207 Accordingly, considerations of public policy (ranging from the deontological to the consequentialist) ${ }^{208}$ must play a central role in all tort adjudication,

\footnotetext{
Ibid at 58-63.

Ibid, ch 7.

Ibid at 206 .

Ibid.

See Cane, Responsibility, supra note 45 (discussing the "symbiotic” relationship between practical moral reasoning and legal reasoning at 14$)$.

203 See ibid, chs 1, 6; Cane, Anatomy, supra note 45, ch 7.

204 Cane, Responsibility, ibid at 188-89, ch 2; cf Tony Honoré, “The Morality of Tort Law-Questions and Answers" in Owen 73, supra note 45 (noting prospective behaviour-guiding function of tort law at 7677); see similarly Ripstein, "Philosophy,” supra note 114 at 663. on "reasons that are extra-legal" at 131).

206 Cane, Anatomy, ibid at 15-18.

207 Ibid at 227 [emphasis added].

208 Cane, Responsibility, supra note 45 at 186-91.
} 
even where these considerations concern objectives lying outside the particular bipolar litigant relationship. ${ }^{209}$

The structural amenability of Cane's theory to protecting privacy is evidenced in two key ways. First, by placing protected interests at the core of tort law and arguing that the vindication of these is tort's primary concern, his approach makes room for the rights-based analysis actually adopted in Campbell, Hosking, and Jones, and recommended by Warren and Brandeis. ${ }^{210}$ This is doubly so, given Cane's emphasis on the importance dignity interests plays in the law of tort. Second, Cane's conception of correlativity brings to the fore the essential balancing not just of the litigants' interests, but also those of society more generally, as a core feature of all tort adjudication. This is important, since any privacy tort will involve careful balancing of privacy with expression, which necessitates looking to the value of speech in light of the wider public interest. Under Cane's conception, tort can easily do this work.

The normative amenability of Cane's scheme to protecting privacy is also evidenced in two key ways. First, by imbuing his “anatomy” with principles of practical morality, he makes room for judges to appeal to the various deontological arguments offered in support of privacy both in the creation and in the doctrinal refinement of any privacy tort. ${ }^{211}$ Second, his emphasis on the forward looking functions of tort law, and the practical necessity of courts drawing upon various consequentialist considerations when adjudicating tort claims, has both principled and practical importance for the resolution of privacy claims. As mentioned, when balancing privacy with expression, courts assess the relative strength of the latter interest engaged in a particular case by considering the "value of the speech." It is thus important, as a matter of principle, that courts also consider consequentialist arguments when evaluating the strength of the privacy interest at hand. Anything less would suggest an unacceptable a priori preference being accorded to speech over privacy (since the analysis would be unbalanced). Furthermore, as a practical matter, functional arguments help guide the analysis by adding specificity and concreteness to the balancing exercise. This becomes clear if we consider the difficulty courts would face if they had to balance privacy with expression based solely on deontological considerations. The arguments in such a case would be largely irreconcilable, as both parties would assert that dignity, autonomy, and respect for them as persons means their respective rights to privacy and speech should be vindicated. Focusing on the functional aspects of privacy provides a way out of this dilemma, for it enables courts to concentrate on the specific (functional) value of the privacy claim (both to the individual, and to society) being advanced in the case before them in light of the nature of intrusion, before balancing it against the specific (functional) importance of the speech at

Recall that Weinrib rejects all considerations lying outside the bipolar dispute before the court when creating or scoping rights of action. Zipursky, following Posner, makes room for consequentialist considerations when creating rights, but does not think such reasoning is permissible when adjudicating their scope. Cane's approach, being the most flexible and practical, probably gets us closest to the truth of what judges in fact do. See Steyb LJ's statement in McFarlane v Tayside Health Board [2000] 2 AC 59 (HL) at 83:"The truth is that tort law is a mosaic in which principles of corrective justice and distributive justice are interwoven. And in situations of uncertainty and difficulty a choice sometimes has to be made between the two approaches." See the discussion in Part III.E, above, applying Stevens’ account to privacy.

For an elaboration of the importance of these considerations to privacy, refer to my discussion above of Wright's substantive CJ account in Part III.D, and to the points made in relation to Stevens' rights based conception in Part III.E. 
hand. Cane's account makes room for such an analysis, and is particularly amenable to adjudicating privacy claims as a result.

\section{AnAlogies to Existing ToRTS}

The arguments above illustrate that a civil claim for invasion of privacy fits within the conceptual superstructure of tort law and resonates with its normative foundations as variously defined by leading theorists. The aim of this section is to demonstrate that a privacy tort can be further justified by appealing to values and principles underpinning defamation and trespass. While analogies to other torts could also be drawn, these two are especially powerful because they are the oldest torts known to the common law, and pertinent because they cover complaints arising from both disclosures of information and intrusions into protected spaces. The argument below buttresses the argument above: asking tort to protect privacy does not ask it to do work of a type fundamentally different from that which it has been doing for centuries.

\section{A. “Dignity” AND “Civility" PROTECTED in DEFAMATION AND PRIVAcy}

For centuries, litigants have turned to the tort of defamation to vindicate a right to reputation. There is widespread agreement among courts that human dignity is the core value underpinning this right. ${ }^{212}$ There has also been recognition, both in England and in the European Court of Human Rights, that, like privacy, defamation claims are now anchored in article 8 of the European Convention on Human Rights. ${ }^{213}$ This "symmetry" between privacy and defamation has been noted by academics ${ }^{214}$ and courts. ${ }^{215}$

Reynolds v Time Newspapers Ltd, [2001] 2 AC 127 (HL) 201 (“[r]eputation is an integral ... part of [a person's] dignity" at 201); Hill v Church of Scientology, [1995] 2 SCR 1130 [Hill] (reputation serves the "fundamentally important purpose of fostering our self-image and sense of self-worth" at para 117, and "represents and reflects the innate dignity of the individual" at para 120; Rosenblatt $v$ Baer, 383 US 75 (1966) ("[reputation] reflects no more than our basic concept of the essential dignity and worth of every human being" at 92); Robert C Post, "The Social Foundations of Defamation Law: Reputation and the Constitution" (1986) 74:3 Cal L Rev 691 [Post, "Defamation"], (referring to the last of these statements as being "enormously influential" in American jurisprudence, and as representing an "authentic contemporary expression of common law understanding of the law of defamation" at 707708).

213 Convention for the Protection of Human Rights and Fundamental Freedoms, 213 UNTS 221, art 8 (entered into force 23 March 1976) [ECHR]. See e.g. Mosley v News Group, [2008] EWHC 1777, [2008] EMLR 20 at para 214 (QB). For a further discussion, see also Dario Milo, Defamation and Freedom of Speech (Oxford: Oxford University Press, 2008) at 21-23, quoting Chauvy v France, No 64915/01, [2004] VI ECHR 205 at para 70. Note that ECHR, art 8 mandates a "respect" for "private and family life." Like the Canadian Charter of Rights and Freedoms, Part I of the Constitution Act, 1982, being Schedule B to the Canada Act 1982 (UK), 1982, c 11 [Charter], the ECHR does not strictly apply to non-government private parties. However, the English courts infuse the principles of the ECHR into private law (invoking a doctrine called the "horizontal" application of $E C H R$ values) in the same way that Canadian courts invoke the principle of "Charter values" to modify changes to the common law. Indeed, "horizontality" was the impetus for the House of Lords to create the modified privacy/confidence action in Campbell, supra note 2, paras 49-51 and for the Ontario Court of Appeal to create a privacy tort in Jones, supra note 5 at para 45.

214 Milo, ibid at 22-23; Post, “Community,” supra note 73 at 964; William L Prosser, “Privacy” (1960) 48:3 Cal L Rev 383 at 398.

215 Hill, supra note 212 (rights to privacy and reputation are "intimately related" at para 121); Roberson v Rochester Folding-Box Co, 71 NYS 876 (App Div 1901) [Roberson] (in an early American privacy case the dissent saw "no distinction in principle" between injuring one's reputation and injuring one's feelings by violating one's privacy at 879 ). 
However, it has been suggested that an important distinction exists between the values underpinning privacy and defamation, in that the former concerns the injury done to a man's esteem of himself, whereas the latter concerns injury to the individual in his external relations, i.e. how others view him. ${ }^{216}$ A related issue is this: if defamation is concerned with one's public reputation, how can it be anchored in the values of dignity at all, since dignity is characteristically concerned with one's private personality? ${ }^{217}$

Robert Post, in his influential exposition of defamation, has convincingly overcome the latter objection by illustrating that one's private identity is dependent upon his public interactions, and that defamation law serves both public and private functions that respond to this reality. ${ }^{218}$ In doing so, he has also bridged the alleged disjunction between the dignity basis of privacy and defamation. Below, I outline Post's arguments, which demonstrate that the American torts of privacy and defamation have a similar dignity basis and perform similar social functions.

Post's argument is grounded in the symbolic interactionist school of sociology associated with its most influential exponent, Erving Goffman. ${ }^{219}$ Goffman's insight was that humans are socially constructed, meaning the development of one's personality is dependent upon the social interactions between him and his community. Communities, in turn, are also defined by these same interactions. Goffman calls such interactions rules of deference and demeanour. Rules of deference refer to conduct by which a person conveys appreciation "to a recipient of this recipient"; and rules of demeanour refer to conduct by which a person expresses to others "that he is a person of certain desirable or undesirable qualities."220 Together, these rules (which Post calls "rules of civility") constitute norms of "conduct which bind the actor and the recipient together [and] are the bindings of society."221 Importantly, "[b]y following these rules, individuals both confirm the social order in which they live and constitute 'ritual' and 'sacred' aspects of their own identity."222 Goffman put it thus:

Each individual is responsible for the demeanour image of himself and the deference image of others, so that for a complete man to be expressed, individuals must hold hands in a chain of ceremony, each giving deferentially with proper demeanour to the one on the right what will be received deferentially from the one on the left. While it may be true that the individual has a unique self all his own, evidence of this possession is thoroughly a product of joint ceremonial labor, the part expressed through the individual's demeanour being no more significant than the part conveyed by others through their deferential behaviour toward him. $^{223}$

See Warren \& Brandeis, supra note 160 at 197-98; cf Percy H Winfield, “Privacy” (1931) 47:1 Law Q $\operatorname{Rev} 23$ at 40 .

See Post, "Defamation," supra note 212 (noting this “paradox" at 707-708).

Ibid. Post's thesis as it pertains to defamation has been endorsed by Milo, supra note 213 at 33-41; and Post's argument as to the parallel functions of privacy and defamation law (discussed below) has been endorsed by Rosen, supra note 30 at 2128.

Erving Goffman, Interaction Ritual: Essays in Face-to-Face Behavior (New Brunswick, NJ: Transaction, 2007).

Ibid at 56,77 [emphasis in original], quoted in Post, "Defamation,” supra note 212 at 709.

Goffman, ibid at 90; Post, "Defamation," ibid at 709-10.

Post, "Defamation," ibid at 709 [footnotes omitted].

Goffman, supra note 219 at 84-85. 
This “'sacred' aspect of identity," referring as it does to the "self's integrity," is an expression of essential human dignity; this "[d]ignity can only be confirmed by the respect that is its due,"224 and where rules of civility are broken (by spreading untruths, and thereby evidencing a lack of such respect) dignity is offended. This also has implications for the development of one's personality, since evidencing such disrespect undermines the victim's "own sense of intrinsic self-worth, stored in the deepest recesses of [his or her] 'private personality.",225 Thus, the esteem with which a man is held in the eyes of others is intimately connected to the esteem with which he regards himself. As mentioned, these "rules of civility" not only confer moral title on individuals as complete persons, they also reflect the social boundaries through which a society defines itself by "develop[ing] an orderly sense of [its] own cultural identity."226

According to Post, the "dignity that defamation law protects is thus the respect (and selfrespect) that arises from full membership in society."227 Crucially,

[i]mplicit in the concept of reputation as dignity, therefore, is the potential for a dual function for defamation law: the protection of an individual's interest in dignity, which is to say his interest in being included within the forms of social respect; and the enforcement of society's interest in its rules of civility, which is to say its interest in defining and maintaining the contours of its own social constitution. ${ }^{228}$

In a subsequent article, Post applied the same arguments to the American privacy torts of intrusion and disclosure of private information. ${ }^{229}$ Briefly, the intrusion tort recognizes and protects what Goffman called "territories of the self." ${ }^{230}$ By protecting these territories, the law safeguards the respect each person is due by virtue of these claims. Intrusions into private territories evidence a lack of respect (an offence to dignity) and, in doing so, also undermine the victim's belief that his "existence is his own" (since his independence is bundled up with his entitlement, respected by others, to control access to his self), which is a precondition to personhood. ${ }^{231}$ The disclosure torts operate in an analogous manner: "just as individuals expect to control certain spatial territories, so they expect to control certain informational territories."232 Accordingly, "the public disclosure branch of the tort ... maintain[s] those civility rules which establish information preserves, in the same way that the intrusion branch upholds the civility rules which define spatial territories."233 Finally,

Post, "Defamation," supra note 212 at 709-10.

Ibid at 710; cf Milo, supra note 213 (endorsing Post's argument and noting that to defame someone is to treat him as an object, offending the Kantian imperative to treat people as ends not means at 35); $c f$ Steven J Heyman, "Righting the Balance: An Inquiry Into the Foundations and Limits of Freedom of Expression” (1998) 78:5 BUL Rev 1275 (making the same point at 1339).

Post, "Defamation,” ibid at 711, quoting Kai T Erikson, Wayward Puritans: A Study in the Sociology of Deviance (New York: John Wiley \& Sons, 1966) at 13. This is because through rules of civility a society distinguishes members from non-members: "Persons who are socially acceptable will be included within the forms of respect that constitute social dignity; persons who are stigmatized as deviants will be excluded" (Post, "Defamation," ibid).

Post, "Defamation," ibid.

Ibid.

Post, “Community," supra note 73.

Ibid at 971-73; Erving Goffman, Relations in Public: Microstudies of the Public Order (New York: Basic Books, 1971) at 28.

Post, “Community,” ibid at 973-74. Post’s argument here tracks Reiman’s “personhood” argument discussed briefly in Part II of this article, above.

Ibid at 984 .

Ibid at 985 . 
Post emphasizes that, like defamation law, these privacy torts have a dual function. ${ }^{234}$ They not only protect the individual's dignity interest, but they also enforce rules of civility for the sake of society itself, because doing so maintains society's "distinctive shape, its unique identity."235

This brief discussion reveals there is nothing discordant about protecting privacy in tort law. Doing so simply calls upon tort to vindicate a dignity interest and thereby uphold rules of civility for the sake of society, something it has been doing under the rubric of defamation for centuries. ${ }^{236}$ Of course, torts of defamation and privacy must have different doctrinal features, the most important being that the former concerns false and the latter true information. But this does not detract from the analogy drawn above, for this doctrinal difference is related to the very nature of reputation, ${ }^{237}$ not to the foundational dignity interest that underlies it.

David Howarth has recently challenged Post's analysis of defamation's core functions. ${ }^{238}$ Drawing on recent research, Howarth contends that Post's reliance on the "looking glass self theory” is problematic for two reasons. ${ }^{239}$ First, Howarth notes that it is not obviously - or necessarily empirically - true that the image an adult has of himself will change when he is defamed or treated with disrespect. There is evidence, Howarth notes, that people have more durable self identities than Post suggests. ${ }^{240}$ Second, Howarth notes that psychologists now draw a distinction between an individual's "self-concept," which is "what one thinks of oneself," and "self-esteem," which is the "idea that it is valuable and desirable for individuals to think of themselves as important, or to feel pride in themselves."241 Howarth notes that recent research has debated, and often doubted, whether the pursuit of self-esteem is actually psychologically or socially desirable. ${ }^{242}$ Howarth concludes that it is "unwise to ground the law of defamation on such contested terrain."243

Howarth argues that defamation's core purpose is to protect reputation, and reputation is important because it performs the central function of helping people "form and maintain social bonds." 244 Howarth cites psychological evidence showing that all people have a fundamental interest in the "formation and maintenance of social relationships," which he calls "sociality." ${ }^{245}$ Howarth notes that defamatory statements injuring a person's reputation often damage social bonds, which in turn can result in lost opportunities and cause "direct damage in terms of a sustained reduction in well-being."246 Howarth concludes that

Ibid at 964.

Ibid at 964, citing Erikson, supra note 226 at 11; cf Bloustein, supra note 38 (advancing similar argument, emphasizing both the intrinsic and wider social values served by enforcing rights to privacy and vindicating personal dignity at 1000-1005).

Callinan, supra note 172 (a privacy tort would perform functions similar to defamation insofar as it would be aimed at "improv[ing] social behaviour and deter[ring] like conduct" at 10).

Lawrence McNamara, Reputation and Defamation (Oxford: Oxford University Press, 2007) at 1.

David Howarth, “Libel: Its Purpose and Reform” (2011) 74:6 Mod L Rev 845.

Ibid at 854-55.

Ibid.

Ibid at 855 .

Ibid.

Ibid.

Ibid at 849.

Ibid.

Ibid. 
defamation should be understood as protecting this fundamental human interest in sociality, and that this is preferable to Post's empirically suspect "looking glass” theory.

If Howarth's arguments are right, then it seems the analogy between privacy and defamation outlined above is not as clear as Post contends. This is because defamation is not necessarily based on the damage done to a person's self-image or self-esteem, in the same way that Post argues privacy is. In response, I would make three points. First, although Howarth's arguments are strong, they are not conclusive. Post's “looking glass” approach is also strong. It is based on a long line of sociological research, it has a certain intuitive appeal, and Post's arguments have been widely cited by many privacy and defamation scholars. In short, it is certainly arguable that Post's view should stand. Second, even if Howarth's argument is right, there is still an analogy to be drawn between privacy and defamation - albeit a less perfect one than Post proposes. Many scholars have argued that privacy is a socialized right. Forced disclosures of private information can damage the bonds of intimacy and, especially if the information is discreditable, can affect the way other people view and treat the victim. This in turn can damage the victim's capacity to form meaningful relationships in the future, cause lost opportunities, lead to ostracization, and result in real damage to the victim's well-being. ${ }^{247}$ In other words, even if we ignore the "looking glass" theory of the development of self, many of the same deleterious effects to sociality that Howarth applies to defamation can also apply to invasions of privacy. Moreover, the extrinsic functions of both privacy and defamation identified by Post — namely, the interest society itself has in maintaining its rules of civility — are not affected by Howarth's critique. Third, and perhaps most importantly, even if Howarth is right and the analogy between defamation and privacy is inapt, this does not defeat the central argument of this paper. My core assertion is that elucidated in Part III, above: a civil claim for invasion of privacy fits within the conceptual superstructure of tort law, and resonates with tort's normative foundations and social purposes as exposited by leading theorists in the field. The arguments advanced in this section are designed simply to buttress the argument advanced above. Even if these analogies fail, the argument in Part III can stand on its own. Indeed, it is the primary argument advanced. ${ }^{248}$

\section{B. “Personal Exclusivity” Protected in Trespass AND Privacy}

Russell Brown has recently argued that a tort of invasion of privacy can be justified by appealing to the idea of "exclusivity" which he views as the normative principle underlying the "resource" interests in one's body and property protected in the torts of battery and trespass. ${ }^{249}$ Importantly, Brown's conception of tort law more generally is anchored in the rights-based models discussed in Part III.E, above. Thus, for Brown the "wrongs" of tort are acts that interfere with a person's "resources"; and "resources” refers to "an interest which the law will protect."250

For a detailed discussion of several scholars making these points, see Hunt, "Conceptualizing," supra note 15 at 213-16.

This is because tort law covers a wide array of actions, many of which do not operate in analogous ways. What unites tort conceptually is not the analogies between heads of liability, but rather the theoretical work discussed in Part III, above.

Brown, "Privacy," supra note 13 at 604-608.

Ibid at 605. Brown endorses the language of normative gains and losses thus evidencing a broad agreement with CJ accounts of tort law's superstructure. 
For Brown, justifying a tort of privacy by analogy involves first understanding which resource interests the law already protects, and then considering why it does so. According to Brown, bodily integrity and property are the paradigmatic resources protected in private law. The reason tort protects these is because interferences with them are offensive to our intuitive sense of social propriety. Although "[b]eing intuitive, an explicit rationale is elusive" - it is simply the case that our intuition here "instantiates the view that tort law's 'special morality' embodies societal values that allow persons to co-exist in communities while maintaining their own autonomy and respecting the autonomy of others." ${ }^{\text {"251 Because }}$ respect for bodily integrity and property is necessary for leading an autonomous life, tort law safeguards these interests by conferring juridical rights in relation to the same.

Brown argues that the essential unifying feature and ultimate underlying value of these rights is the principle of "exclusivity," which is the entitlement of holders of these two rights to exclude others from accessing this "resource." And because of its conceptual association with autonomy, the principle of exclusivity has its own "normative force." ${ }^{252}$ Brown concludes that to assert something is "private" is essentially to claim a right of exclusivity; and since breaches of privacy undermine one's claim here, they represent intuitively wrongful violations of personal autonomy in a manner analogous to the torts of battery and trespass. ${ }^{253}$ Importantly, because privacy appeals to the underlying principle of exclusivity in this way, and because exclusivity has its own normative force, it ultimately "does not matter whether we characterize a protected interest in 'privacy' as deriving from ... bodily integrity or ... property." 254 The principle of exclusivity “furnishes its own justification.”255 Brown concludes that a "protected interest in 'privacy' emanates from tort law's coherent and widely shared understanding of juridical right, descriptive of a person's interest in his or her property or bodily integrity, which underpins tort law’s protective norms."256

The essence of Brown's argument has both historical and contemporary support. Warren and Brandeis, in their seminal article that gave birth to the American privacy tort, borrowed the notion of a common law right “to be let alone” from Justice Cooley’s seminal tort text ${ }^{257}$ which used this phrase to justify why tort law protects against assaults not involving direct physical contact. ${ }^{258}$ The same idea found favour with the dissenting judges in the New York Court of Appeal in one of the earliest privacy cases. ${ }^{259}$ More recently, Goldberg and Zipursky, in the course of defending their theoretical conception of torts as "wrongs," have asserted that battery and assault share the "central” interest of "maintaining one's 'personal space," from unwelcome "intrusions," which they share in common with privacy torts. ${ }^{260}$ Tort law regards such intrusions wrongful because they “interfer[e] with the victim's ability

Ibid at 606, 614 [footnotes omitted]. This view essentially replicates Risptein's argument, discussed in Part III.C, above.

Ibid at 606 .

Ibid at 606-608.

Ibid at 606.

Ibid.

Ibid at 590-91 [footnotes omitted].

Warren \& Brandeis, supra note 160 at 195; Cooley, supra note 64 at 29.

See Neil M Richards \& Daniel J Solove, "Privacy's Other Path: Recovering the Law of Confidentiality" (2007) 96:1 Geo LJ 123 at 130, for a discussion of this point. 
to interact with others."261 In their view, these intrusions undermine one’s autonomy; and because they do so in a manner offensive to the "positive morality of the community," they "became part of the law of torts."262

Echoing the argument of Post (in Part IV.A, above), Zipursky and Goldberg also see a wider principle uniting the dignity-interest torts of battery and trespass, on the one hand, with defamation and privacy, on the other. In each case, the relevant "wrong” not only offends the victim's autonomy, but it does so in a manner that "involves the defendant acting so as to alter in a deleterious way how others view the victim," ${ }^{263}$ thereby stifling his capacity to develop as a complete person. Finally, they emphasize the important functions these torts serve for maintaining what Post calls the "rules of civility” that underpin society's moral identity. ${ }^{264}$

\section{CONCLUSiON}

In Douglas, Lord Phillips, in the English Court of Appeal, said “invasion of ... privacy might seem most appropriately to fall within the ambit of the law of delict." 265 Justice Tipping, in the New Zealand Court of Appeal, went a little further, suggesting why in his view this is so: "[i]nvasion of privacy is a common law wrong which is founded on the harm done to the plaintiff by conduct which can reasonably be regarded as offensive to human values."266 The purpose of this article was to confirm through theoretical explication the veracity of these judicial assertions. My aim was to show, first, that a civil claim for invasion of privacy fits within the conceptual superstructure of tort law, and that it resonates with tort's normative foundations and social purposes as variously exposited by leading theorists in the field. This argument was buttressed with a second one, which was to identify the fundamental similarities between privacy and the torts of defamation, on the one hand, and battery and trespass, on the other. Taken together, my aim was to fit a "right" of privacy into the "wrongs" of tort, and my argument was that protecting privacy under an independent tort does not require tort law to do work of a kind any different in substance from that which it is already doing.

These jurisprudential arguments have numerous potential practical implications. Courts in Ontario ${ }^{267}$ and Nova Scotia ${ }^{268}$ have only recently decided that invasion of privacy is a common law wrong, and the (unanalyzed) assumption to date has been that tort is the most appropriate basis for these claims. It is not inconceivable, however, that as these courts (or those in other provinces) move forward with refining these actions, they may be influenced by the increasingly mature English breach of confidence approach. Indeed, this is a very real possibility for jurisdictions like Alberta, New Brunswick, and Prince Edward Island, that do

$261 \quad$ Ibid at 940.

$262 \quad$ Ibid at $953, \mathrm{n} 180$.

263 Ibid at 940 [emphasis added].

264 Ibid at 973-76 (“" t] $]$ he provision by a government ... of a law of wrongs and recourse embodies and furthers several related liberal-democratic values. [I]t affirms the significance of the individual citizen[;] ... confers upon each of us duties not to mistreat others ... [; and] it [thereby] embodies and reinforces a notion of democratic equality” at 981-82).

Douglas, supra note 10 at para 96.

Hosking, supra note 4 at para 246.

Jones, supra note 5.

Trout Pond Lodge Ltd v Handshoe, 2012 NSSC 245, 320 NSR (2d) 22. 
not have statutory privacy actions, and whose courts have not yet had the occasion to recognize independent common law privacy actions. ${ }^{269}$ If so, various doctrinal implications may follow, for the principles of equity may exert different pressures on the ambit, and features, of these claims, in matters as diverse as: the requisite mental element; the available defences; the awarding of exemplary damages and restitutionary relief; and the applicable limitation periods, to name but a few. If the arguments in this paper are correct, and tort law is the preferable foundation for such claims, then courts need to pause before importing equitable principles into their adjudication. They should instead consult long-established tort doctrines to inform their approach to vindicating invasions of privacy. 